Illinois State University

ISU ReD: Research and eData

Theses and Dissertations

$10-6-2020$

\title{
Big Data On Midwest Farms: Assessment Of Use, Concerns, And Challenges
}

Frederick Adomako

Illinois State University, fadomako21@gmail.com

Follow this and additional works at: https://ir.library.illinoisstate.edu/etd

Part of the Agriculture Commons

\section{Recommended Citation}

Adomako, Frederick, "Big Data On Midwest Farms: Assessment Of Use, Concerns, And Challenges" (2020). Theses and Dissertations. 1327.

https://ir.library.illinoisstate.edu/etd/1327

This Thesis is brought to you for free and open access by ISU ReD: Research and eData. It has been accepted for inclusion in Theses and Dissertations by an authorized administrator of ISU ReD: Research and eData. For more information, please contact ISUReD@ilstu.edu. 


\section{BIG DATA ON MIDWEST FARMS: ASSESSMENT OF USE, CONCERNS, AND}

\section{CHALLENGES}

\section{FREDERICK ADOMAKO}

\section{Pages}

Farming is undergoing a digital revolution (Bronson \& Knezevic, 2016). The advent of plant genetics, chemical inputs, and more recently guidance systems have transformed the industry into one that is increasingly technology-intense and data-rich (Stubbs, 2016).

Concerns are being raised including big agricultural companies' control of a data trove that presents privacy and business risks to farmers who do not want to share their operational data with competitors or the government (Singh \& Kaskey, 2014). An overwhelming majority of agricultural producers believe farm data belongs to them (Banham, 2014). This belief of ownership has resulted in much discussion of developing a farm data exchange - an arrangement, in which producers could be compensated for sharing of their data (Shickler, 2015; Banham, 2014; Singh \& Kaskey, 2014).

The purpose of this study is to identify factors that influence U.S. agricultural producers' adoption of Big Data technologies focusing on the Midwestern region and some of the challenges these farmers encounter in the acquisition, use and control of the gathered data for production management and agricultural decision-making purposes. A survey was conducted to collect data from farmers in Illinois, Indiana and Iowa. The survey was distributed to 12,176 farmers and had a 2.4 percent response rate with 241 complete responses. About 90 percent of farmers belief their farm data belonged to them. About 79 percent of farmers were concerned 
about how their farm data was shared, 79 percent were concerned about third parties who used their farm data while 78 percent were concerned about third party access to their farm data.

A Poisson regression model was used to identify factors influencing the number of technologies adopted by farmers. Results showed a statistically significant relationship between acres farmed and adoption group of farmers. Results of the binary logistic regression showed that, the age of farm operator, educational level of farm operator, number of technologies used on the farm, increase in yield as a reason for using technology and difficulty with understanding data as a reason for not using technology were statistically significant.

KEYWORDS: Agriculture, Big data, Precision agriculture 
BIG DATA ON MIDWEST FARMS: ASSESSMENT OF USE, CONCERNS, AND

CHALLENGES

FREDERICK ADOMAKO

A Thesis Submitted in Partial

Fulfillment of the Requirements for the Degree of

MASTER OF SCIENCE

Department of Agriculture

ILLINOIS STATE UNIVERSITY

2020 
Copyright 2020 Frederick Adomako 


\section{BIG DATA ON MIDWEST FARMS: ASSESSMENT OF USE, CONCERNS, AND CHALLENGES}

FREDERICK ADOMAKO

COMMITTEE MEMBERS:

Aslihan D. Spaulding, Chair

Iuliia Tetteh

James Wolf 


\section{ACKNOWLEDGMENTS}

My earnest appreciation to God almighty for my life, His protection and wisdom during the period of my graduate study. I would like to also express my heartfelt gratitude to my family especially my parents and aunts who had little to no formal education but saw it necessary to go through all the struggles to help me come this far.

I would like to also say thank you to my advisor and chair of my graduate committee Dr. Aslihan D. Spaulding for her support, advice and guidance during my graduate study. My appreciation also goes out to my thesis committee members Dr. Iullia Tetteh and Dr. James Wolf for their immense encouragement and assistance in successfully completing my thesis. Thanks, are extended to Dr. Michael Barrowclough and Dr. Maria Boerngen for their research expertise and guidance, Kathy Scott and Mary Akers for always ensuring I had the needed support in terms of stationary, mailing of my survey, and all other paperwork for my thesis. I am also thankful to the faculty of the Department of Agriculture who made me feel always at home with their smiles and welcoming hands whenever I needed it.

I want to finally say thank you to Compeer Financial for their financial support, my office mates Godfred Ankomah, Aidan Walton, course mates and friends for contributing to my success here at Illinois State University. I am forever grateful.

F.A. 


\section{CONTENTS}

$\begin{array}{lll}\text { Page } & \end{array}$

ACKNOWLEDGMENTS

$\begin{array}{ll}\text { CONTENTS } & \text { ii }\end{array}$

TABLES

CHAPTER I: INTRODUCTION 1

Background 1

$\begin{array}{ll}\text { Purpose Statement } & 6\end{array}$

$\begin{array}{ll}\text { Thesis Organization } & 6\end{array}$

CHAPTER II: REVIEW OF THE LITERATURE

Factors Affecting Technology Adoption in Agriculture $\quad 8$

CHAPTER III: METHODOLOGY 12

$\begin{array}{ll}\text { Constructing the Variables } & 12\end{array}$

$\begin{array}{ll}\text { Model Specification } & 15\end{array}$

$\begin{array}{ll}\text { Poisson Regression Model } & 15\end{array}$

Binary Logistic Regression 16

$\begin{array}{ll}\text { Limitations of This Study } & 17\end{array}$

CHAPTER IV: RESULTS AND DISCUSSIONS 19

$\begin{array}{ll}\text { Farm and Operator Characteristics } & 19\end{array}$

Characteristics of Adoption Groups (Early vs. Late Adopters) 21

$\begin{array}{ll}\text { Important Features When Choosing Technologies } & 21\end{array}$

Farmers' Perception of Their Farm Data $\quad 22$

Farmers' Preference on How to Access Services by Providers 23 
To Whom Do You Think Farm Data Belongs to?

Are You Comfortable Sharing Your Farm Data With the Following? 24

$\begin{array}{ll}\text { Farm Data Concerns } & 25\end{array}$

Reasons for Using Technologies on the Farm 26

Reasons for Not Using Technologies on the Farm 27

$\begin{array}{ll}\text { Contractual Agreements and Services Received from Providers } & 27\end{array}$

Technology Use, Adoption, Data Collection and Storage by Farmers 28

Farm Size by Adoption Groups (Early vs. Late Adopters) 30

Reasons for Technology Adoption by Adoption Groups (Early vs. Late Adopters) 31

Reasons for Not Adopting Technology by Adoption Groups (Early vs. Late Adopters) 32

Adoption Group (Early vs. Late Adopters) and Farm Data Concerns 34

Factors Affecting Technology Adoption 35

$\begin{array}{ll}\text { Factor Analysis } & 35\end{array}$

Results of Factor Analysis on Farmers' Concerns of Their Farm Data 35

Results of Factor Analysis on Important Features Farmers Consider When

Choosing Technologies $\quad 35$

Results of Factor Analysis of Reasons for Using Technologies 36

Results of Factor Analysis of Reasons for Not Using Technologies 37

Poisson Regression Results $\quad 38$

Binary Logistic Regression Results 39

CHAPTER V: CONCLUSIONS AND RECOMMENDATIONS 42

$\begin{array}{ll}\text { Conclusions } & 42\end{array}$

$\begin{array}{ll}\text { Recommendations } & 43\end{array}$ 
$\begin{array}{ll}\text { REFERENCES } & 44\end{array}$

APPENDIX A: SURVEY COVER LETTER AND CONSENT FORM 53

$\begin{array}{ll}\text { APPENDIX B: SURVEY } & 57\end{array}$

APPENDIX C: MAIL SURVEY: FOLLOW UP LETTER 68 


\section{TABLES}

Table

Page

1. Factors Affecting Big Data Adoption 11

2. Definition of Variables 17

3. Farm and Operator Characteristics 20

4. Average Demographics of Adoption Groups (Early vs. Late Adopters) 21

5. Important Features When Choosing Technologies 22

6. Farmers' Perception of Their Farm Data 23

7. Farmers' Preference on How to Access Services by Providers 23

8. To Whom Do You Think Farm Data Belongs to? 24

9. Are You Comfortable Sharing Your Farm Data With the Following? 25

10. Farm Data Concerns 26

11. Reasons for Using Technologies on the Farm 26

12. Reasons for Not Using Technologies on the Farm 27

13. Contractual Agreements and Services Received from Providers 28

14. Technology Use, Adoption, Data Collection and Storage by Farmers 30

15. Farm Size by Adoption Groups (Early vs. Late Adopters) 31

16. Reasons for Technology Adoption by Adoption Groups (Early vs.

Late Adopters) $\quad 32$

17. Reasons for Not Adopting Technology by Adoption Groups (Early vs.

Late Adopters) 33

18. Adoption Groups (Early vs. Late Adopters) and Farm Data Concerns 34

19. Results of Factor Analysis of Farmers' Concerns of Their Farm Data 35 
20. Results of Factor Analysis of Important Features Farmers Consider When Choosing Technologies

21. Results of Factor Analysis of Reasons for Using Technologies

22. Results of Factor Analysis of Reasons for Not Using Technologies

23. Poisson Regression Results

24. Binary Logistic Regression Results 


\section{CHAPTER I: INTRODUCTION}

\section{Background}

Agriculture plays an integral role across all sectors of an economy. It serves as a major source of employment in the developing world and supports job creation in other sectors of the economy in developed countries. While some may view the agricultural sector as involving only farm-level activities, in many nations its role and impact extend throughout the entire food supply chain.

The U.S. agricultural sector provides 22.2 million jobs, contributing to 11 percent of total employment and over a half of the U.S. land base is used for agricultural purposes (USDA NASS, 2020). In 2019, agriculture food and its related industries contributed $\$ 1.109$ trillion to U.S. GDP, which was approximately 5.2 percent of total GDP. In 2018, agricultural exports were estimated to be $\$ 139.6$ billion, comprising mainly grains and feeds, soybeans, livestock products, fruit, vegetables, and other horticultural products (USDA ERS, 2018).

As of 2017, there were over two million farms across the U.S. (USDA NASS, 2019). The U.S. agriculture sector is predominantly crop and livestock production. U.S. crop production is concentrated mainly in California, Florida, and the Midwest. Crops mainly produced by U.S. farmers include corn, soybean, wheat, and upland cotton (USDA, 2018). Livestock produced in the U.S. are mainly: dairy cattle, beef cattle, hogs, goats, and sheep. In 2017, the U.S. produced 26.5 billion pounds of livestock with production expected to exceed 29 billion pounds by 2027 (USDA, 2018).

Farming is undergoing a digital revolution (Bronson \& Knezevic, 2016). The advent of plant genetics, chemical inputs, and more recently guidance systems have transformed the industry into one that is increasingly technology-intense and data-rich (Stubbs, 2016). Data 
capturing and storage is continually increasing, by means of mobile technology and data management software. The industry today has readily available external datasets which give a more comprehensive picture of the world in which production agriculture occurs (Stubbs, 2016). In 2015, investors poured $\$ 661$ million into 84 agricultural startups to help farmers transform agriculture into the next big data industry (Pham \& Stack, 2018, Burwood-Taylor et al., 2016). This amount increased to about $\$ 1$ billion in the first quarter of 2018 and 2019 but has shown a decline to about $\$ 550$ million in the first quarter of 2020 due to the COVID-19 pandemic (Day, 2020).

The current state of agriculture is experiencing an increased collection and use of data by both farmers and private firms. Data is collected from a variety of sources and is used by farmers and input suppliers to boost productivity, address water and environmental concerns, and lower costs (Pham \& Stack, 2018). With the availability of Global Positioning Systems (GPS) and other technologies, producers can track yields, steer and control equipment, monitor field conditions, and manage inputs at very precise levels across fields, substantially increasing productivity and profitability (Estes, 2016). Farm machines in today's agriculture are equipped with sensors and cameras that capture field-level data like soil moisture, leaf greenness, temperature, seeding, fertilizer and pesticide spraying rate, yield, fuel usage, and machine performance (Pham \& Stack, 2018). Approximately 70 percent of tractors in the U.S. have GPS with auto steering technologies and 40 percent of all corn farms can potentially use yield monitors (Schimmelpfennig, 2016). According to Sykuta (2016), survey by the Agricultural Resource Management showed that, over 62 percent of corn and soybean acres in the U.S. were harvested with yield monitoring devices and 73 percent of acres were farmed using some type of precision agriculture practice. 
Though Big Data presents various opportunities for the agricultural sector, it also poses issues regarding data access and ownership. Many producers are skeptical of data storage companies' data handling practices which has prompted discussions by several articles (Castle et al., 2016). Singh and Kaskey (2014, para. 2) state that "big agricultural companies could now control a data trove that presents privacy and business risks to farmers who do not want to share their operational data with competitors or the government." An overwhelming majority of agricultural producers believe farm data belongs only to them (Banham, 2014). Producers in Nebraska are no exception to this belief as according to Castle et al. (2015), 100 percent of 126 agricultural producers from across the state belief that farm data belonged to farmers. These concerns have prompted discussions for the development of a farm data exchange, in which producers could be compensated for sharing of their data (Shickler, 2015; Banham, 2014; Singh \& Kaskey, 2014).

For example, John Deere has sensors fitted to John Deere tractors that provide farmers with real-time information on soil and crop conditions. Farmers subscribe and pay for access to collected and analyzed data by John Deere to help them make farm-level decisions. John Deere tractors are proprietary, thus data collected by these tractors is not openly accessible to farmers (Bronson \& Knezevic, 2016).

Big Data has the potential to increase the supply of data across various segments in agriculture: from the plant genome to water management, fertilization, climate, soil, machinery, and crop protection systems (Estes, 2016). Some of the examples of such technologies include variable rate application, GPS-enabled sensors to name a few. Variable rate application technologies can distribute different amounts of agronomic input (e.g. fertilizer, irrigation, and herbicide) across the same field to match actual need of the input (Basso et al., 2017). GPS- 
enabled sensors are being used to track food and generate agricultural Big Data of supply chains (Shekhar et al., 2017). The use of such technologies is estimated to help reduce food-borne illnesses which affects an estimated 76 million people in the U.S. every year thus saving the lives of 5,000 people who die from food-borne illnesses every year. (Estes, 2016).

Bronson and Knezevic (2016) define Big Data as the use of large information sets and the digital tools for collecting, aggregating and analyzing collected data. Big Data represents the information assets characterized by high volume, velocity and variety (3 V's) as to require specific technology and analytical methods for its transformation into value (Wolfert et al., 2017). Basso et al. (2017); also define Big Data as the collection, analysis, and synthesis of large data sets that may (or may not) originate from precision agriculture equipment. Big Data application in agriculture is often viewed as a combination of technology and analytics that can collect and compile novel data and process data in a more useful and timely way to assist decision-making (Shekhar et al., 2017; Stubbs, 2016).

According to Estes (2016. Para. 4), "Big Data is being applied in the following areas of the food chain:

- Development of new seed traits: discoveries and access to the plant genome with new ways to measure, map, and drive information into better products, faster.

- Precision Farming: although sometimes used interchangeably, Big Data and precision agriculture are not synonymous. Big Data takes advantage of information derived through precision farming in aggregate over many farms. The resulting analytics, insights, and better decisions can then be deployed through precision farming techniques.

- Food Tracking: use of sensors and analytics to prevent spoilage and food borne illnesses". 
Big Data proponents promise a level of precision, information storage, processing, and analysis that was previously impossible due to technological limitations (Basso et al. 2017; Stubbs, 2016; Rijmenam, 2013). A study conducted by the Agricultural Information Management Standards (AIMS) team of the Food and Agriculture Organization indicated that "Big Data could provide new efficient decision-making tools for helping agricultural development as well as biodiversity protection. New acquired, aggregated, and shared data is a breeding ground for extracting and sharing useful information and knowledge among different actors involved in agriculture or biodiversity domains, as well as for combining large data sources with advanced crop and environment models to provide actionable on-farm decisions" (FAO 2016, para. 1)

The majority of Big Data research in agriculture is focused on its potential benefits (Elezaj \& Tole, 2018; Gustafson, 2014; Manyika et al., 2011), challenges (Coble et al., 2018; Bronson \& Knezevic, 2016; Haire, 2014; Labrinidis \& Jagadish, 2012; Kouzes et al., 2009) and ethics (Richterich, 2018; Carbonell, 2016) with limited attention given to factors that influence farm-level adoption of Big Data technologies. The rate of adoption of new agricultural technologies is increasing, despite low commodity prices and sustained low farm incomes (Estes, 2016). According to Tene and Polonetsky (2013), data creates enormous economic value for the world economy, driving innovation, productivity, efficiency, and growth. To ensure collected data is useful for business decision making, there is the need for analytical tools to interpret the collected data. For a better understanding and realization of the potential benefits Big Data adoption and usage can offer the agricultural sector and the rate of adoption by agricultural producers, there is the need for agricultural producers and other relevant stakeholders, to adopt big data technologies for use in their operations. Despite the optimism of adopting Big Data for 
agricultural purposes, it also brings with it questions about the factors that affect farmers' adoption of Big Data.

\section{Purpose Statement}

The purpose of this study is to identify factors that influence U.S. agricultural producers' adoption of Big Data technologies focusing on the Midwestern region and some of the challenges these farmers encounter in the acquisition, use and control of the gathered data for production management and agricultural decision-making purposes. Therefore, this study will help measure the effect that farmer and farm-level characteristics have on the adoption of Big Data technologies in their production and management decision-making process. Results of this study will add to the existing knowledge of literature and may assist stakeholders and policymakers to better understand rates of adoption of Big Data technologies and the concerns of users within the agricultural sector.

\section{Thesis Organization}

This thesis includes a general introduction, a review of literature, methodology, discussion of results and recommendations and survey materials in an appendix. 


\section{CHAPTER II: REVIEW OF THE LITERATURE}

"For many years, farmers used their own judgment and guesswork to guide tractors" (Strobel, 2015, p. 240) "until the incorporation of information technologies into agricultural production practices in the mid-1980s" (National Research Council, 1997, p. 17). Though many of the tools for precision agriculture were developed over many years, the 1990s saw many new technologies being developed (Brase, 2000). "It is interesting to note that major changes in agricultural technology have often been treated with derision and controversy: the change from horses to tractors was difficult for many people, moving from single cross corn seed to hybrid seed was controversial as some people argued that we were playing God with plants" (Brase, 2000, p. 2).

Precision agriculture as cited by Strobel (2015), has been noted as one of the top technological advances in engineering of the twentieth century. "The fundamental concept of precision agriculture was collecting data and making decisions based on that data and it has been around for many years. Precision agriculture originated with the Geographic Information System (GIS) and has advanced to the guidance systems and variable rate technique through technological development" (Brase, 2000, p. 2). The term precision agriculture was formally recognized in the U.S. by the drafting of a bill on precision agriculture by the U.S. Congress in 1997 (Whelan \& Taylor, 2005). "Many definitions of precision agriculture exist, and many people have different ideas of what precision agriculture should encompass" (Whelan \& Taylor, 2005, p. 2). However, the first actual definition of precision agriculture came from the U.S. House of Representatives (1997) and they defined precision agriculture as "an integrated information- and production-based farming system that is designed to increase long term, sitespecific and whole farm production efficiency, productivity, and profitability while minimizing 
unintended impacts on wildlife and the environment" (Zarco-Tejada et al., 2014, p. 11).

Precision agriculture can be categorized under three components: "capture of data at an appropriate scale and frequency, interpretation and analysis of that data, and implementation of a management response at an appropriate scale and time" (National Research Council, 1997, p. 17).

Precision agriculture tools are grouped under five major components: GIS, GPS, Variable Rate Technologies (VRT), Yield Monitoring and Mapping (YM), and Sensors (Rains \& Thomas, 2009; Brase, 2000). “A key difference between conventional management and precision agriculture is the application of modern information technologies to provide, process, and analyze multisource data of high spatial and temporal resolution for decision making and operations in the management of crop production" (National Research Council, 1997, p. 17).

\section{Factors Affecting Technology Adoption in Agriculture}

The innovation-diffusion process covers decisions, activities, and impacts that come from needs or problems (Almeida et al., 2017; Rogers, 1983). The innovation adoption process has three typical phases: initiation, adoption (decision), and implementation (Bremser \& Piller, 2017; Damanpour \& Schneider 2006; Zmud, 1981). "During the initiation phase individuals become aware of an innovation, consider its use for a recognized need and propose its adoption. In the adoption phase proposed ideas are evaluated from technical, financial, and strategic perspectives. Then an adoption decision is taken; which includes the allocation of resources for the implementation and assimilation of an accepted solution. All preparations for its productive use are then carried out during the implementation phase" (Bremser \& Piller, 2017, p. 2). 
The immediate and uniform adoption of a new technology occur at a slow pace in the agricultural sector. "The delay in adoption can be attributed to factors such as credit constraints, limited access to information, risk aversion, inadequate farm size, inadequate human capital, and inadequate incentives due to tenure arrangements" (Feder et al., 1985, p. 1; Gedikoglu, 2008, p. 20). Anderson et al. (2014); posit that, the key challenges relating to big data on the farm to be: human capital (farmers needing to be tech-savvy), quality data, data access, better data analytics, and agronomic data held by agriculture retailers.

Results from several researches conducted in the U.S. show that, adoption rates are high for yield monitors but sluggish for other technologies such as variable rate application (Schimmelpfenning \& Ebel, 2016; Erickson et al., 2017; Griffin et al. 2017). Technologies that require the farmer to acquire additional knowledge to operate (such as variable rate technology) have lower adoption rates than those that can be integrated using existing knowledge (such as GPS guidance) (Griffin et al., 2017; Turland, 2018). According Turland (2018), the adoption of technologies does not only depend on the individual considering the adoption, but on the characteristics of the technology itself. Mark et al. (2016), suggest that, improving wireless connectivity is a primary driver of the adoption of Big Data technologies. Schimmelpfennig and Ebel (2011), report that "adopters of yield monitor technologies, GPS mapping, and VRT fertilizer technologies for corn and soybean production produced significantly higher yields than non-adopters in 2001 and 2005. The difference in yield for adopters was between 10 percent to 14 percent higher than non-adopters. Their study also indicates that profitability is likely to affect adoption rates".

Surbakti et al. (2020), identified 41 factors affecting Big Data technology adoption. They however categorized these factors into seven themes including the following categories: data 
quality, data privacy and security and governance, perceived organizational benefit, process management, people aspects, systems, tools, and technologies, and organizational aspects. According to Boyer et al. (2015), farmers have a positive view of Big Data. They however value traditional management tools over more advanced technologies. Their study also found that few participants indicated high awareness of data security and other risks and increased concern about data security was not associated with age or education. Farmer perceptions of Big Data are informed by the marketing tactics employed by companies that sell Big Data technologies services (Turland, 2018).

Agrawal (2015), explored the high-level determinants that influence the adoption of Big Data analytics in emerging economies. The study showed that complexity, competition intensity, compatibility, regulatory support, environmental uncertainty, and organizational size were found to be significant determinants. Of the determinants, regulatory support and complexity were inhibitors and most influential, all the other factors were facilitators of adoption. Economic and profit motivation are dominant factors driving the adoption of Big Data in agriculture (Sonka, 2015). Kamilaris et al. (2017); found that as the availability and variety of hardware and software needed to collect and analyze Big Data increases, farmers will be more willing to adopt technology resulting in the increased public sector initiatives and business ventures in the agricultural sector.

Yadegaridehkordi et al. (2018), studied the significant factors affecting Big Data adoption and how these factors influence the performance of manufacturing companies by using a hybrid approach of decision-making trial and evaluation laboratory (DEMATEL) - adaptive neuro-fuzzy inferential systems (ANFIS). The authors categorized factors affecting the adoption of Big Data by manufacturing companies in Malaysia as technological, organizational and 
environmental dimensions. Their research findings indicate that, technological factors (perceived benefits, complexity, technology resources, Big Data quality and integration) have the highest influence on Big Data adoption and firm's performance. Other studies that grouped factors affecting Big Data adoption as technological, organizational and environmental are presented in the table below.

\section{Table 1:}

Factors Affecting Big Data Adoption

\begin{tabular}{|c|c|c|c|}
\hline Dimension & Malaka, Brown (2015) & Agrawal (2015) & Nam et al. (2015) \\
\hline Environmental & $\begin{array}{l}\text { - Industry/market } \\
\text { competition } \\
\text { - Vendor reliance } \\
\text { - Data security and } \\
\text { privacy }\end{array}$ & $\begin{array}{l}\text { - Environmental } \\
\text { uncertainty } \\
\text { - Competition } \\
\text { intensity } \\
\text { - Regulatory support }\end{array}$ & $\begin{array}{l}\text { - Perceived industry } \\
\text { pressure } \\
\text { - Perceived } \\
\text { government }\end{array}$ \\
\hline Technological & $\begin{array}{l}\text { - Time and cost } \\
\text { - Data integration } \\
\text { - Veracity } \\
\text { - Performance and } \\
\text { scalability }\end{array}$ & $\begin{array}{l}\text { - Complexity } \\
\text { - Compatibility } \\
\text { - Relative advantage }\end{array}$ & $\begin{array}{l}\text { - Perceived direct } \\
\text { benefits } \\
\text { - Perceived indirect } \\
\text { benefit }\end{array}$ \\
\hline Organizational & $\begin{array}{l}\text { - Ownership and control } \\
\text { - Skill shortage } \\
\text { - Communication } \\
\text { processes }\end{array}$ & $\begin{array}{l}\text { - Technological } \\
\text { resource } \\
\text { competency } \\
\text { - Organizational size } \\
\text { - Absorptive } \\
\text { capacity }\end{array}$ & $\begin{array}{l}\text { - Perceived financial } \\
\text { readiness } \\
\text { - Perceived } \\
\text { information systems } \\
\text { competence }\end{array}$ \\
\hline
\end{tabular}

Source: Bremser et al. 2017 


\section{CHAPTER III: METHODOLOGY}

A survey with twenty-three (23) questions targeted at farmers in Illinois, Indiana and Iowa was designed and used for data collection. Survey included several questions addressing farmers' demographics and farming operation information, technology use by farmers, data sharing and ownership concerns, and challenges of use of gathered data. Surveys were distributed to farmers by e-mail listserv and mail. An email with the survey was sent to 11,556 farmers through Farm Progress Show listserv between November 2019 and January 2020. Three follow-up emails were sent to non-respondents to remind them of the survey. A paper copy of the survey along with a cover letter, pre-addressed and pre-stamped envelope were mailed out to 620 farmers in Northern Illinois in December 2019. Three weeks later, follow-up survey was mailed out to non-respondents. It should however be noted that, the paper survey only included farmers located in Northern Illinois due to access to contact information and financial constraints. A non-response bias test between first and second responders as well as, between mail and online survey showed no statistically significant difference. A total of 293 (222 online survey and 71 mail survey) respondents consented to participate in this survey. Due to missing data, some of the responses were excluded as a result, 241 responses were used for the purpose of analysis.

\section{Constructing the Variables}

In deciding which variables to use as independent variables, some analyses had to be done due to the differences in the types of variables used. In all, a total of eight different factors were identified as potentially affecting the number of technologies adopted by farmers and 12 factors identified as affecting the likelihood of farmers being early or late adopters. 
The first factor identified to potentially affect the number of technologies adopted in this study was farmer's age. Respondents were asked to indicate their year of birth. This was later converted to age in years for each respondent.

The educational level of respondents was also identified as a potential independent variable. Question 3 asked respondents to indicate the highest level of education you have completed. Respondents were to choose from 10 options between "no formal education to Graduate degree (M.S., M.A, Ph.D., etc.)". For the purposes of this study, respondents with "no formal education" was given a value of 1 and those that had attained a graduate degree (M.S., M.A, Ph.D., etc.) was coded 10.

Acres farmed was another independent variable used in this study. Respondents were asked to indicate the number of acres that they farmed in 2018.

Adoption group was also identified as a potential independent variable. Respondents were asked to indicate where they saw themselves in the adoption of technology. Respondents had the following options from which they were to select one option. "I am on the forefront of new technology, I am above average when it comes to adopting new technology, I am slowly catching up with new technology, I have a long way to go with new technology". Respondents were grouped as early or late adopter based on responses for this question. All respondents who indicated "they were on the forefront of new technology and those that were above average when it came to the adoption of a new technology" were considered early adopters. All respondents who indicated "they were slowly catching up with new technology and those that had a long way to go with new technology" were considered late adopters. Early adopters were thus given a value of 1 and late adopters were given a value of 0 for the purpose of analysis for this study. 
Respondents were asked to indicate their concerns regarding their farm data. Respondents had thirteen concerns from which they were to select all that applied to them. To ensure the most pressing concerns were used in the analysis of this study, a factor analysis was conducted to select the variables that really reflected the concerns of respondents. Four variables were identified after the factor analysis and used as independent variable for this study. Cybersecurity threat concerns, lack of skilled personnel for data interpretation, concerns of storage capacity and, concerns of third-party use of farmers' data were the concerns with the highest loadings under each factor.

In constructing the independent variables for the binary regression model, farmer characteristics including farmer's age, educational level and acres farmed were used. It also included certain features respondents considered as important when choosing which big data technology to use on their farm. Question 14 of the survey asked respondents to choose from 14 features which they considered important when choosing these technologies. The model also included reasons for which respondents would use or not use big data technologies on their farm. Question 20 and 21 asked respondents to indicate their reasons for using or not using big data technologies on their farms. A factor analysis was conducted to reduce the number of independent variables for the purpose of this study. After the analysis, availability of data storage, ease of use of technology, service provider offers interpretation of data were the three most important features respondents considered when choosing which big data technologies to use, increased yield, ease of recordkeeping were reasons why respondents use big data technologies, and high cost of investment, size of operation (too small to justify), difficulty with understanding the data were identified as reasons why respondents would not use big data technologies. 
Number of technologies used by respondents on the farm. Question 11 asked respondents to select from 13 technologies respondents used on their farms. Each technology selected was assigned a value of 1 and those that were not selected assigned a 0 . To know the number of technologies each respondent uses on his/her farm, I summed up the number of technologies each respondent use to get the total number of technologies they use on their farms.

\section{Model Specification}

\section{Poisson Regression Model}

Following Paxton et al., (2010), Castle et al. (2016) and Abdulai et al. (2018), a Poisson regression model was used to estimate the individual effects of selected independent variables on the dependent variable. The dependent variable of interest is the count of the number of technologies that is used by farmers. According to Britt et al. (2017), count refers to the simple accumulation of the number of times some event occurs during a fixed time interval or within a spatial unit at a fixed point in time. The Poisson model with a log link function was used in analyzing the effect of age, education, acres farmed, adoption group, who uses my farm data, cybersecurity threats, lack of skilled personnel for data interpretation and storage cost on the number of technologies adopted by farmers in Illinois, Iowa and Indiana. The Poisson regression is expressed by the equation:

$$
\operatorname{Pr}(X=x)=\frac{e^{-\lambda} \lambda^{x}}{x !} \quad \mathrm{y}=0,1,2,3 \ldots \ldots
$$

According to Abdulai et al. (2018), the parameter $\lambda$ is assumed to be log-linearly related to the independent variable $\left(\mathrm{X}_{\mathrm{i}}\right)$ and dependent variable $(\mathrm{Y})$. A Poisson random variable with its probability density function is given as: 
$f\left(Y_{i} / X_{i}\right)=\frac{\mu^{Y} e^{-\mu}}{Y_{i}} \quad \mathrm{Y}=0,1,2,3 \ldots$

Where $f(Y)$ represents the probability that $Y$ takes non-negative integer values, and $\left(Y_{i}\right)$ denotes $Y \times(Y-1) \times(Y-2) \times 2 \times 1$. Since the variance and mean are equal, the Poisson regression model can be written as:

$Y_{i}=E\left(Y_{i}\right)+u_{i}=\mu_{i}+u_{i}$

For estimation purposes, the parameter $\mu_{i}$ which takes a log linear function form is used:

$\ln \left(\lambda_{i}\right)=B^{\prime} X_{i}$

\section{Binary Logistic Regression}

To assess the likelihood of farmers being early or late adopters, a binary logistic regression was used. The independent variables used were age of operators, educational level of operators, acres farmed, availability of data storage, ease of use of the technology, service provider offers interpretation of data, increased yield from use of technology, ease of recordkeeping from use of technology, high cost of investment, size of operation (too small to justify), number of technologies used by farm operator on the farm, difficulty with understanding the data. The statistical model is specified below:

$$
\begin{aligned}
& \log \left(\frac{\pi}{1-\pi}\right)=\beta_{0}+\beta_{1} \text { Age }+\beta_{2} \text { Edu }+\beta_{3} \text { Acres }+\beta_{4} \text { Datasto }+\beta_{5} \text { Etechuse }+\beta_{6} \text { Serprointer }+\beta_{7} \text { Yield } \\
& +\beta_{8} \operatorname{Re} \text { ckeep }+\beta_{9} \text { High } \cos t+\beta_{10} \text { Sizeop }+\beta_{11} \text { Numbtech }+\beta_{12} \text { Diffunderstanding } \\
& \pi=P(Y=1)
\end{aligned}
$$


Table 2:

\section{Definition of Variables}

\section{Variable}

Age

Edu

Acres

Datasto

Etechuse

Serprointer

Yield

Reckeep

Highcost

Sizeop

Numbtech

Diffunderstanding

Adoptgroup

Cybersecurity

Datainterpretation

Storagecost

Usage

Dependent variable (Poisson

regression)

Dependent variable (Binary

regression)

\section{Description}

Farm operator's age

Farm operator's level of education

Acres farmed

Availability of data storage

Ease of use of technology

Service provider offers interpretation of data

Increased yield from use of technology

Ease of recordkeeping from use technology

High cost of investment

Size of operation (too small to justify)

Number of technologies used by farm operator on the farm

Difficulty with understanding data

Technology adoption group of farm operator

Concerns of threat of cybersecurity

Concerns of lack of skilled personnel for data interpretation

Concerns of cost of storage of data

Concerns of who uses operator's farm data

Number of technologies used on the farm

Early vs. late adopters

\section{Limitations of This Study}

Due to how the survey was distributed to respondents, there may be some errors in the randomness of the survey distribution. Respondents of the online survey are farmers who attend the Farm Progress Show and have minimum farmland size of about 100 acres. This means that, the survey distribution may have potentially omitted farmers who do not attend the Farm Progress Show and may have farmland size smaller than 100 acres. It should however be noted that, some respondents of the survey had less than 100 acres of operations. Again, farmers who 
responded to the online survey must have had access to internet connection to have completed the survey. This may have excluded farmers who are less technologically oriented, had no or limited access to internet connection from the research sample. Also, due to limited access to a more comprehensive list and financial constraints, the mail survey was only distributed to 621 farmers located within Northern (42 counties of) Illinois. This may also have potentially excluded respondents who may have had interest in this study.

Following Dillman (2014), and using an 80/20 split, the total responses of 241 for this survey has a $5 \%$ margin of error. There results of analysis of a response bias showed that, there was no statistically significant response bias between early respondents and late respondents and mail and online respondents. This indicates that, the responses received reflects a representation of the study population. 


\section{CHAPTER IV: RESULTS AND DISCUSSIONS}

\section{Farm and Operator Characteristics}

Table 3 shows farm and operator characteristics of respondents. The majority $(90$ percent) of respondents were males with ten percent being females. The average age of respondents was 60 years which is slightly higher than the reported average age of 58 in Illinois, 56 in Indiana, 57 in Iowa and 58 years of farmers in the U.S. in 2017 (USDA, 2017). Baby boomers (people born between 1946-1964) and the silent generation (people born between 19251945) accounted for the 70 percent of the respondents and 21 percent and seven percent belonged to the generation X (people born between 1965-1980), and millennials (people born between 1981-1996) respectively. About 53 percent of respondents had attained a bachelor's degree or higher, 46 percent had high school or some college education while the remaining one percent had less than high school education. Majority of respondents (89) percent had 11 or more years of farming experience whiles ten percent were beginning farmers (farming for ten years or less). Almost half of the respondents (49) percent operate small farms (farmers with gross farm income of less than $\$ 350,000$ ), about a third (29) percent represent medium size farms (farmers with gross farm income between $\$ 350,000$ and $\$ 999,999$ ) and 14 percent were large size farms (farmers with gross income greater than $\$ 1$ million).

The majority of operators were involved in grain production: corn ( 92 percent), soybean (87 percent), wheat (16 percent) and hay, alfalfa, rye, cover crops, hemp among others. Some respondents also had livestock enterprise as well and reported the following: beef cattle (25 percent), hogs (eight percent), poultry (three percent), sheep (three percent), equine (two percent), dairy (two percent), goats (one percent) and other farm animals (two percent) including bees, dairy heifer, and alpaca. 
Farmers were asked to comment on certain needs this survey may not have addressed. It should be noted that, only $4 \%$ of the respondents made some comments and as a result, these comments are not shown in the study.

Table 3:

Farm and Operator Characteristics

\begin{tabular}{|c|c|c|}
\hline Demographics & & Percentage of Respondents \\
\hline \multirow{2}{*}{ Gender } & Male & $90 \%$ \\
\hline & Female & $10 \%$ \\
\hline \multirow{3}{*}{ Age } & Silent and Baby Boomers & $70 \%$ \\
\hline & Generation $\mathrm{X}$ & $21 \%$ \\
\hline & Millennials & $7 \%$ \\
\hline \multirow{3}{*}{ Education } & Less than high school & $1 \%$ \\
\hline & High school and some college & $46 \%$ \\
\hline & Bachelor's degree or higher & $53 \%$ \\
\hline \multirow{2}{*}{ Years of farming } & Beginning farmers (10 years or less) & $10 \%$ \\
\hline & $11+$ years & $89 \%$ \\
\hline \multirow{3}{*}{$\begin{array}{l}\text { Gross farm } \\
\text { income }\end{array}$} & Small size farms & $49 \%$ \\
\hline & Medium size farms & $29 \%$ \\
\hline & Large size farms & $14 \%$ \\
\hline \multirow{4}{*}{ Crops raised } & Corn & $92 \%$ \\
\hline & Soybeans & $87 \%$ \\
\hline & Wheat & $16 \%$ \\
\hline & Other & $20 \%$ \\
\hline \multirow[t]{8}{*}{ Livestock raised } & Beef cattle & $25 \%$ \\
\hline & Hogs & $8 \%$ \\
\hline & Sheep & $3 \%$ \\
\hline & Poultry & $3 \%$ \\
\hline & Equine & $2 \%$ \\
\hline & Dairy & $2 \%$ \\
\hline & Goats & $1 \%$ \\
\hline & Other & $2 \%$ \\
\hline
\end{tabular}




\section{Characteristics of Adoption Groups (Early vs. Late Adopters)}

Table 4 shows farmer characteristics of adoption groups. The average age of early adopters was 58 years whiles that of late adopters was 62 years. Majority of early adopters had completed a four-year college or higher degree with majority of late adopters being two-year college degree or higher graduates. The average acres farmed by an early adopter is 1,738 acres and that of late adopters is 869 . Early adopters had an average of 32 years of farming experience while late adopters had an average of 36 years of farming experience. The average number of technologies used by early adopters was eight while that of late adopters was five.

\section{Table 4:}

Average Demographics of Adoption Groups (Early vs. Late Adopters)

\begin{tabular}{|l|c|c|}
\hline & $\begin{array}{c}\text { Early } \\
\text { Adopters } \\
\text { N= 108 }\end{array}$ & $\begin{array}{c}\text { Late } \\
\text { Adopters } \\
\mathbf{N}=\mathbf{1 0 5}\end{array}$ \\
\hline Age & 58.35 & 62.12 \\
\hline Education (Years) & 8 & 7 \\
\hline Acres Farmed & 1738 & 869 \\
\hline Years of Farming & 32 & 36 \\
\hline Number of Technologies Used & 8 & 5 \\
\hline
\end{tabular}

\section{Important Features When Choosing Technologies}

Respondents were asked to indicate the important features they consider when choosing which technology to use on their farms. Table 5 shows that, over 90 percent of farmers consider the cost of service, ease of interpretation of data, ease of use of the data, ease of use of the technology, the economic benefits from using the technology, quality of data analysis, time saving, the source of the data, availability of technical support and, the user friendliness of the technology as important when choosing which data technology to use on their farms. It was 
surprising to find 18 percent of the farmers considered the environment benefits as not at all important.

\section{Table 5:}

Important Features When Choosing Technologies

\begin{tabular}{|l|c|c|}
\hline & Important & Not at all important \\
\hline User friendly & $97 \%$ & $3 \%$ \\
\hline Ease of use of technology & $95 \%$ & $5 \%$ \\
\hline Cost of the service & $94 \%$ & $6 \%$ \\
\hline Ease of interpretation of data & $94 \%$ & $6 \%$ \\
\hline Ease of use of the data & $94 \%$ & $6 \%$ \\
\hline Economic benefits from using the technology & $94 \%$ & $6 \%$ \\
\hline Time saving & $94 \%$ & $6 \%$ \\
\hline Technical support & $94 \%$ & $6 \%$ \\
\hline Quality of data analysis & $93 \%$ & $7 \%$ \\
\hline Source of the data & $90 \%$ & $10 \%$ \\
\hline Availability of decision support tools & $85 \%$ & $15 \%$ \\
\hline Environmental benefits & $82 \%$ & $18 \%$ \\
\hline Service provider offers interpretation of data & $82 \%$ & $18 \%$ \\
\hline Availability of data storage & $79 \%$ & $21 \%$ \\
\hline
\end{tabular}

\section{Farmers' Perception of Their Farm Data}

Question 15 asked farmers to indicate their level of agreement with the following statements. Table 6 shows that, over seventy percent agreed Big Data would transform how things are done on the farm in the next 20 years. About seventy-one percent agreed they could store the data generated from on their farms. Over half of the farms agreed the collected data from other sources for decision making and knew how to protect their farm data. 


\section{Table 6:}

Farmers' Perception of Their Farm Data

\begin{tabular}{|l|c|c|}
\hline Do you agree with the following statements........ & Yes & No \\
\hline Big data will transform how we do things on the farm in the next 20 years. & $72 \%$ & $28 \%$ \\
\hline I am able to store data generated on my farm. & $71 \%$ & $29 \%$ \\
\hline I know how to interpret data generated on my farm for decision making. & $68 \%$ & $32 \%$ \\
\hline I know how to use data generated on my farm. & $65 \%$ & $35 \%$ \\
\hline I know who has access to my farm data. & $60 \%$ & $40 \%$ \\
\hline $\begin{array}{l}\text { I acquire data from other sources for decision making purposes on my } \\
\text { farm. }\end{array}$ & $53 \%$ & $47 \%$ \\
\hline I know how to protect my farm data. & $53 \%$ & $57 \%$ \\
\hline
\end{tabular}

\section{Farmers' Preference on How to Access Services by Providers}

Table 7 shows the results of farmers' perception of data ownership and their preference to access of services by providers. Over fifty percent of farmers prefer to access these services via email and website. About forty-five percent of farmers prefer text messaging while forty-one percent prefer the use of mobile apps. About 2 percent of farmers preferred one-on-one and group meetings and, phone calls as other means of accessing the services by providers. Over ninety percent of farmers believed their farm data belonged to them. About 7 percent believed input providers have a share of ownership of their farm data.

Table 7:

Farmers' Preference on How to Access Services by Providers

\begin{tabular}{|l|c|}
\hline Data Access & Yes \\
\hline Email & $53 \%$ \\
\hline Website & $53 \%$ \\
\hline Text message & $45 \%$ \\
\hline Mobile app & $41 \%$ \\
\hline One-on-one meeting & $39 \%$ \\
\hline Other (please specify) & $2 \%$ \\
\hline
\end{tabular}




\section{To Whom Do You Think Farm Data Belongs to?}

Question 17 asked farmers to indicate whom they thought their farm data belonged to. Table 8 shows the results of their responses. The majority (ninety percent) believed their farm data belong to themselves. About 7 percent of farmers believed their farm data belonged the input providers. Some of the farmers also believed that, the company that manufactured the equipment had 4 percent ownership of their farm data and 2 percent believed their farm data belonged to equipment dealers.

\section{Table 8:}

To Whom Do You Think Farm Data Belongs to?

\begin{tabular}{|l|c|}
\hline & Yes \\
\hline Farmer & $90 \%$ \\
\hline Input provider & $7 \%$ \\
\hline The company that manufactured the equipment & $4 \%$ \\
\hline Equipment dealer & $2 \%$ \\
\hline Other & $2 \%$ \\
\hline
\end{tabular}

\section{Are You Comfortable Sharing Your Farm Data With the Following?}

Table 9 shows the results of how comfortable farmers are when it comes to sharing their data with third parties. Over sixty percent of farmers indicated they were comfortable sharing their farm data with crop insurance providers, fifty-six percent and forty-seven percent of farmers were comfortable sharing their farm data with financial institutions and university researchers respectively. 


\section{Table 9:}

Are You Comfortable Sharing Your Farm Data With the Following?

\begin{tabular}{|l|c|}
\hline & Yes \\
\hline Crop insurance provider & $69 \%$ \\
\hline Financial institutions & $56 \%$ \\
\hline University researchers & $47 \%$ \\
\hline Input suppliers & $39 \%$ \\
\hline USDA & $37 \%$ \\
\hline Equipment manufacturers & $31 \%$ \\
\hline Grower associations & $25 \%$ \\
\hline State agency & $24 \%$ \\
\hline Salespeople & $21 \%$ \\
\hline Other federal agency & $16 \%$ \\
\hline None of the above & $5 \%$ \\
\hline Other (please specify) & $1 \%$ \\
\hline
\end{tabular}

\section{Farm Data Concerns}

Table 10 shows the results of concerns of farmers regarding their farm data. The results showed that, over seventy percent of farmers had concerns regarding the use and ownership of their farm data, cybersecurity threats, how their farm data is protected, how their farm data is shared, third parties' access to their farm data. Just about a third of farmers had concerns regarding storage capacity. 
Table 10:

Farm Data Concerns

\begin{tabular}{|l|c|c|}
\hline I am concerned about.......................... & Yes & No \\
\hline Who uses my farm data & $79 \%$ & $21 \%$ \\
\hline How my farm data is shared & $79 \%$ & $21 \%$ \\
\hline Who has access to my farm data & $78 \%$ & $22 \%$ \\
\hline Who owns my data & $77 \%$ & $23 \%$ \\
\hline How my data is protected & $74 \%$ & $26 \%$ \\
\hline Cybersecurity threats & $71 \%$ & $29 \%$ \\
\hline Quality of the data from other sources & $62 \%$ & $38 \%$ \\
\hline Access to data from other sources & $59 \%$ & $41 \%$ \\
\hline Availability of decision support tools & $55 \%$ & $45 \%$ \\
\hline Lack of skilled personnel for data analysis & $54 \%$ & $46 \%$ \\
\hline Lack of skilled personnel for data interpretation & $54 \%$ & $46 \%$ \\
\hline Storage cost & $45 \%$ & $55 \%$ \\
\hline Storage capacity & $39 \%$ & $61 \%$ \\
\hline
\end{tabular}

\section{Reasons for Using Technologies on the Farm}

Table 11 shows the results of reasons why farmers choose to use technologies on their farms. About 79\% indicated they used technologies on their farms due to increased productivity. Only about a third of the farmers use technologies because it saves time and gives them the ability to be innovative.

\section{Table 11:}

Reasons for Using Technologies on the Farm

\begin{tabular}{|l|c|c|}
\hline & Yes & No \\
\hline Increased productivity & $79 \%$ & $21 \%$ \\
\hline Ease of recordkeeping & $77 \%$ & $23 \%$ \\
\hline Increased yield & $77 \%$ & $23 \%$ \\
\hline Increased farm profit & $76 \%$ & $24 \%$ \\
\hline Ease of documentation & $71 \%$ & $29 \%$ \\
\hline Time saving & $66 \%$ & $34 \%$ \\
\hline Allows me to be innovative & $65 \%$ & $35 \%$ \\
\hline
\end{tabular}




\section{Reasons for Not Using Technologies on the Farm}

Table 12 shows the results of reasons why farmers would not use technologies on their farms. Over seventy percent of farmers would not use technologies because the cost of investing in technologies was too high. More than half of the farmers were uncertain of the return on their investment in technologies.

\section{Table 12:}

Reasons for Not Using Technology on the Farm
\begin{tabular}{|l|c|c|}
\hline Reasons for NOT using technology & Yes & No \\
\hline High cost of investment & $72 \%$ & $28 \%$ \\
\hline Uncertain return on investment (ROI) & $59 \%$ & $41 \%$ \\
\hline Lack of technical support & $49 \%$ & $51 \%$ \\
\hline Do not trust source of data & $42 \%$ & $58 \%$ \\
\hline Size of operation (too small to justify) & $42 \%$ & $58 \%$ \\
\hline Difficulty with learning technology & $41 \%$ & $59 \%$ \\
\hline Difficulty with using technology & $41 \%$ & $59 \%$ \\
\hline Difficulty with understanding the data & $37 \%$ & $63 \%$ \\
\hline Close to retirement or farm transition & $32 \%$ & $68 \%$ \\
\hline Not worth my time & $27 \%$ & $73 \%$ \\
\hline Other (please specify) & $2 \%$ & $98 \%$ \\
\hline
\end{tabular}

\section{Contractual Agreements and Services Received from Providers}

Question 22 asked farmers if they had at least one contractual agreement with service providers and to indicate the kind of services they receive from the service providers. Table 13 shows the responses from the farmers. About $48 \%$ of the farmers have at least one contractual agreement with service providers. About twenty-one percent of the farmers indicated they had data collection contractual agreement with service providers. Farmers that had data storage and data analysis contracts were fourteen and twelve percent respectively. About 9 percent had data 
interpretation contracts and 7 percent had advisory services contract. About 2 percent of the farmers indicated they received other forms of services including weather services, rain total forecast among others.

\section{Table 13:}

Contractual Agreements and Services Received from Providers

\begin{tabular}{|l|c|}
\hline & Yes \\
\hline Contract with service providers & $48 \%$ \\
\hline Services received from providers & \\
\hline Data collection & $21 \%$ \\
\hline Data storage & $14 \%$ \\
\hline Data analysis & $12 \%$ \\
\hline Data interpretation & $9 \%$ \\
\hline Advisory services & $7 \%$ \\
\hline Other & $2 \%$ \\
\hline
\end{tabular}

\section{Technology Use, Adoption, Data Collection and Storage by Farmers}

Table 14 shows technology use by farmers on their farms. Farmers were asked to indicate what technologies they use on their farms. The results show a widespread use of yield monitors (77 percent), GPS (73 percent) and field mapping (73 percent) technologies among respondents. This is consistent with study conducted by: (Turland 2018; Erickson et al. 2017; Griffin et al. 2017; Schimmelpfenning and Ebel 2016; Castle et al. 2015). Only three percent of the farmers indicated they used other technologies including aerial surveillance, digital sensors, LED lighting, IoT in grain semis, remote precipitation monitoring, and satellite photography.

As of the adoption of new technology, about 40 percent of the farmers believed they were above average, 27 percent were slowly catching up with new technologies, 19 percent have a long way to go in the adoption of new technologies and eight percent are on the forefront of 
adopting new technologies. Majority of the respondents (68) percent of farmers indicated that; they collected some form of data from their farming activities whiles 25 percent did not collect any data. Regarding data storage by farmers, about half store data using their business computers, cloud storage (27) percent, and six percent stored data using other means including USB, zip drives, paper copies, file cabinet among others. Interestingly, two percent of the farmers did not know how their farm data was stored. 
Table 14:

Technology Use, Adoption, Data Collection and Storage by Farmers

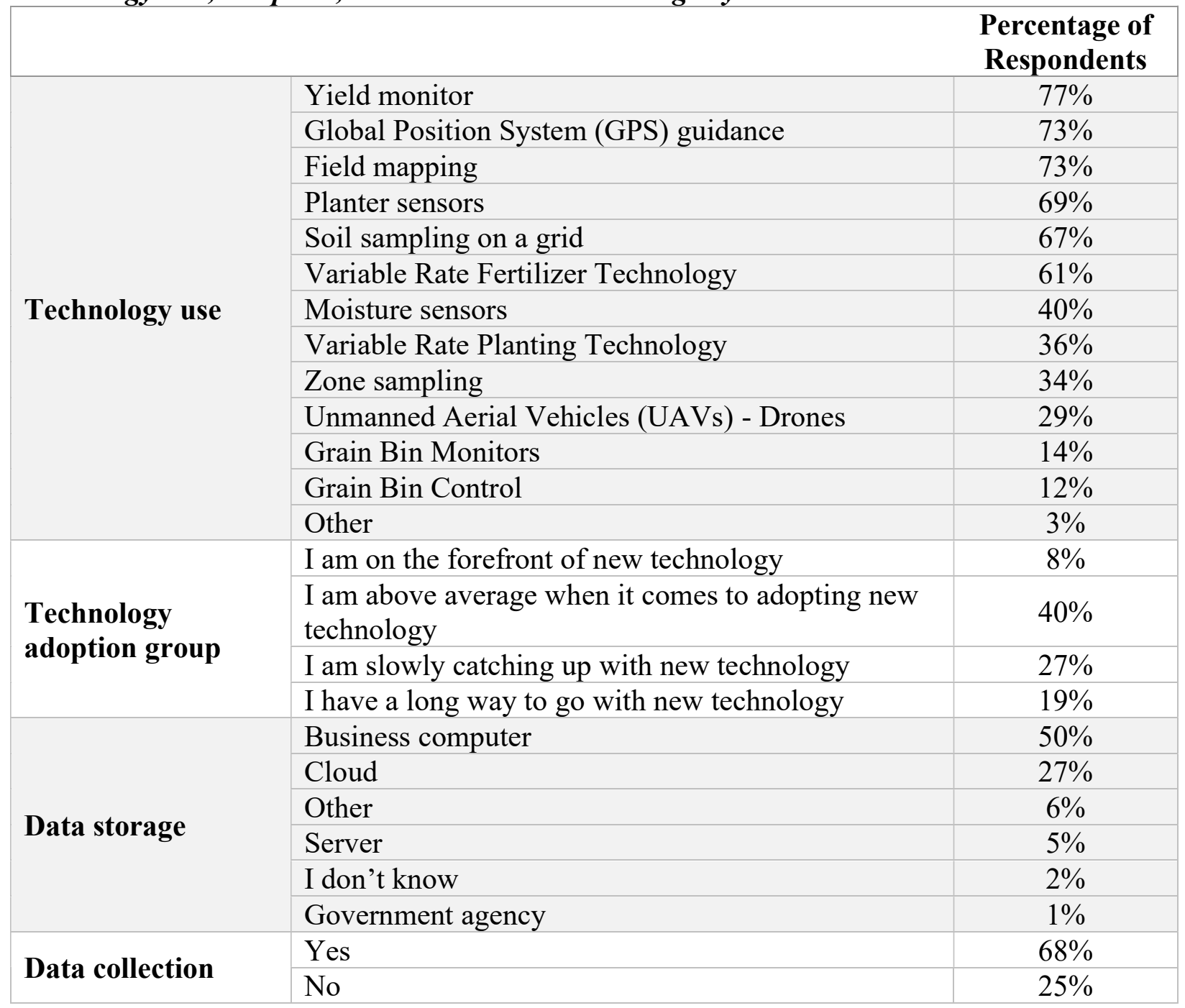

Farm Size by Adoption Groups (Early vs. Late Adopters)

Table 15 shows a cross tabulation between farm size and adoption groups. About 76 percent of operators of small-midsize farms consider themselves to be early adopters compared to about 24 percent of operators of large size farms. The majority (93 percent) of operators of 
small-midsize farms consider themselves to be late adopters compared seven percent of operators of large size farms. A Chi-Square test showed a significant test statistic.

Table 15:

Farm Size by Adoption Groups (Early vs. Late Adopters)

\begin{tabular}{|l|c|c|c|}
\hline & Small-Medium Size Farms & Large Size Farms & p-value \\
\hline Early Adopters & 86 & 27 & .000 \\
\hline Late Adopters & $(76.1 \%)$ & $(23.9 \%)$ & 7 \\
$(99$ & $(6.6 \%)$ & .000 \\
\hline
\end{tabular}

\section{Reasons for Technology Adoption by Adoption Groups (Early vs. Late Adopters)}

Table 16 shows a cross tabulation between reasons for adopting technology and adoption groups. The analysis showed that, 111 out of 202 respondents ( 55 percent) adopt technology because it allows them to be innovative. Majority of respondents (90) percent of early adopters indicated that, the ability to innovate is a reason why they choose to use technologies on their farms compared to only 60 percent of late adopters who cited this reason. More than half (55) percent of respondents indicated they adopted technologies due to ease of documentation from the use of the technology. The majority ( 92 percent) of these respondents were early adopters compared to 75 percent of late adopters. About 54 percent of respondents adopted technologies as a result of increased farm profit. Over half (54 percent) of the respondents indicated they adopt technology because of increased productivity. About 54 percent of the respondents indicated they adopted technologies due to increased yield. Early adopters seem to adopt new technologies due to innovation, ease of documentation, increased farm profit, increased productivity, and increased yield. The results showed that, there is not a statistically significant 
association between ease of recording, time saving, and reduced input costs among the adoption groups.

Table 16:

Reasons for Technology Adoption by Adoption Groups (Early vs. Late Adopters)

\begin{tabular}{|l|c|c|c|}
\hline Allows me to be innovative & Early Adopters & Late Adopters & p-value \\
\hline Ease of documentation & $\begin{array}{c}100 \\
(90.1 \%)\end{array}$ & $\begin{array}{c}55 \\
(60.4 \%)\end{array}$ & .000 \\
\hline Increase farm profit & $\begin{array}{c}101 \\
(91.8 \%)\end{array}$ & $\begin{array}{c}68 \\
(74.7 \%)\end{array}$ & .001 \\
\hline Increased productivity & $\begin{array}{c}106 \\
(95.5 \%)\end{array}$ & $\begin{array}{c}76 \\
(80 \%)\end{array}$ & .001 \\
\hline Increased yield & $\begin{array}{c}82 \\
(96.4 \%)\end{array}$ & .025 \\
\hline
\end{tabular}

\section{Reasons for Not Adopting Technology by Adoption Groups (Early vs. Late Adopters)}

Table 17 shows a cross tabulation between reasons for not adopting technology and adoption groups. About 54 percent of late adopters indicated they were reluctant to adopt technologies because they were close to retirement or farm transition compared to 25 percent of early adopters. Over a third (69 percent) of late adopters find learning new technology difficult compared to 33 percent of early adopters. About (60 percent) of late adopters would not use technologies due to difficulties with understanding the data the technology generates. About 64 percent of late adopters find the use of technology difficult compared to 38 percent of early adopters. Late adopters are therefore more likely to avoid the adoption of technologies for use on their farms because they find it difficult to learn new technologies, difficult to understand the data it generates and difficult to use the data. Technology service providers for agricultural 
producers may focus attention in these areas to help increase adoption by these producers. About 91 percent of late adopters and 79 percent of early adopters find the cost of investment

prohibitive. Both early and late adopters are less likely adopt technologies due to its high cost of investment. About 42 percent of late adopters find technology adoption not worth their time compared to 26 percent of early adopters. Majority of late adopters (66 percent) find the size of their operation too small to adopt technologies in comparison to 36 percent of early adopters. About 79 percent of late adopters find the return on investment (ROI) of technologies uncertain compared to 64 percent of early adopters. There was not a statistically significant relationship between adoption groups and operators' lack of trust in data source and lack of technical support.

Table 17:

Reasons for Not Technology Adoption by Adoption Groups (Early vs. Late Adopters)

\begin{tabular}{|l|c|c|c|}
\hline & $\begin{array}{c}\text { Early } \\
\text { Adopters }\end{array}$ & $\begin{array}{c}\text { Late } \\
\text { Adopters }\end{array}$ & p-value \\
\hline $\begin{array}{l}\text { Close to retirement or farm } \\
\text { transition }\end{array}$ & $\begin{array}{c}27 \\
(24.8 \%)\end{array}$ & $\begin{array}{c}49 \\
(54.4 \%)\end{array}$ & .000 \\
\hline Difficulty with learning technology & $\begin{array}{c}35 \\
(33 \%)\end{array}$ & $\begin{array}{c}63 \\
(69.2 \%)\end{array}$ & .000 \\
\hline $\begin{array}{l}\text { Difficulty with understanding the } \\
\text { data }\end{array}$ & $\begin{array}{c}33 \\
(31.1 \%)\end{array}$ & $\begin{array}{c}54 \\
(60 \%)\end{array}$ & .000 \\
\hline Difficulty with using technology & $\begin{array}{c}40 \\
(37.7 \%)\end{array}$ & $\begin{array}{c}58 \\
(64.4 \%)\end{array}$ & .000 \\
\hline High cost of investment & $\begin{array}{c}84 \\
(77.8 \%)\end{array}$ & $\begin{array}{c}88 \\
(90.7 \%)\end{array}$ & .012 \\
\hline Not worth my time & $(26.2 \%)$ & $\begin{array}{c}37 \\
(42 \%)\end{array}$ & .019 \\
\hline $\begin{array}{l}\text { Size of operation (too small to } \\
\text { justify) }\end{array}$ & $\begin{array}{c}39 \\
(36.4 \%)\end{array}$ & $\begin{array}{c}61 \\
(66.3 \%)\end{array}$ & .000 \\
\hline $\begin{array}{l}\text { Uncertain return on investment } \\
\text { (ROI) }\end{array}$ & $\begin{array}{c}68 \\
(64.2 \%)\end{array}$ & $\begin{array}{c}73 \\
(79.3 \%)\end{array}$ & .018 \\
\hline
\end{tabular}




\section{Adoption Group (Early vs. Late Adopters) and Farm Data Concerns}

Table 18 shows a cross tabulation between adoption groups and the concerns these groups have with the adoption of technologies for use on their farms. About 74 percent of late adopters were concerned with the lack of skilled personnel for data analysis compared with 56 percent of early adopters. Over 70 percent of late adopters were concerned about the lack of skilled personnel for data interpretation. Both early and late adopters are concerned about the lack of skilled personnel for data analysis and data interpretation. About 81 percent of early adopters were concerned about the quality of the data from other sources. There was no statistically significant association between the adoption groups and concerns of access to data from other sources, availability of decision support tools, cyber security threats, protection of farm data, sharing of farm data, storage cost, storage capacity, third party access to farm data, data ownership, and third party usage of farmers' data.

\section{Table 18:}

Adoption Groups (Early vs. Late Adopters) and Farm Data Concerns

\begin{tabular}{|l|c|c|c|}
\hline & $\begin{array}{c}\text { Early } \\
\text { Adopters }\end{array}$ & $\begin{array}{c}\text { Late } \\
\text { Adopters }\end{array}$ & p-value \\
\hline $\begin{array}{l}\text { Lack of skilled personnel for data } \\
\text { analysis }\end{array}$ & $\begin{array}{c}62 \\
(55.9 \%)\end{array}$ & $\begin{array}{c}67 \\
(74.4 \%)\end{array}$ & .006 \\
\hline $\begin{array}{l}\text { Lack of skilled personnel for data } \\
\text { interpretation }\end{array}$ & $\begin{array}{c}62 \\
(56.4 \%)\end{array}$ & $\begin{array}{c}67 \\
(74.4 \%)\end{array}$ & .008 \\
\hline $\begin{array}{l}\text { Quality of the data from other } \\
\text { sources }\end{array}$ & $\begin{array}{c}89 \\
(80.9 \%)\end{array}$ & $\begin{array}{c}60 \\
(68.2 \%)\end{array}$ & .039 \\
\hline
\end{tabular}




\section{Factors Affecting Technology Adoption}

\section{Factor Analysis}

\section{Results of Factor Analysis on Farmers' Concerns of Their Farm Data}

Table 19 shows the results of the factor analysis of farmers' concerns of their farm data.

It can be seen that, who uses my farm data, lack of skilled personnel for data interpretation, storage capacity and cybersecurity threats had the highest loadings thus were selected as independent variables for the Poisson regression model for this study.

\section{Table 19:}

Results of Factor Analysis of Farmers' Concerns of Their Farm Data

\begin{tabular}{|c|c|c|c|c|}
\hline I am concerned about................ & \multicolumn{4}{|c|}{ Component } \\
\hline & 1 & 2 & 3 & 4 \\
\hline Who uses my farm data & .897 & -.043 & .100 & -.016 \\
\hline Who has access to my farm data & .891 & .034 & .037 & -.100 \\
\hline Who owns my data & .641 & .007 & .005 & .261 \\
\hline Lack of skilled personnel for data interpretation & -.026 & .983 & -.023 & .005 \\
\hline Lack of skill personnel for data analysis & .007 & .979 & -.004 & -.061 \\
\hline Storage capacity & -.069 & -.076 & .892 & .020 \\
\hline Storage cost & .123 & -.032 & .761 & -.001 \\
\hline Quality of data from other sources & .108 & .141 & .597 & -.003 \\
\hline Availability of decision support tools & .021 & .313 & .397 & .146 \\
\hline Cybersecurity threats & -.021 & -.004 & -.017 & .856 \\
\hline How my data is protected & .123 & -.064 & -.027 & .806 \\
\hline Access to data from other sources & -.124 & .048 & .213 & .561 \\
\hline How my farm data is shared & .427 & .100 & -.197 & .548 \\
\hline
\end{tabular}

\section{Results of Factor Analysis on Important Features Farmers Consider When Choosing Technologies}

Table 20 shows the results of the factor analysis of the important features farmers consider when choosing technologies for use on their farms. The results show that, ease of use of 
technology, service provider offers interpretation of data and availability of data storage had the highest loadings thus were selected as independent variables for the logistic regression model for this study.

Table 20:

Results of Factor Analysis on Important Features Farmers Consider When Choosing Technologies

\begin{tabular}{|l|c|c|c|}
\hline & \multicolumn{3}{|c|}{ Component } \\
\hline Important Features & $\mathbf{1}$ & $\mathbf{2}$ & $\mathbf{3}$ \\
\hline Ease of use of technology & $\mathbf{. 9 5 3}$ & -.020 & -.021 \\
\hline Ease of use of data & .931 & -.025 & .049 \\
\hline Ease of interpretation of data & 883 & -.006 & .052 \\
\hline User friendly & .632 & .314 & -.096 \\
\hline Cost of the service & .561 & -.094 & .357 \\
\hline Economic benefit from using technology & .494 & .375 & .041 \\
\hline Service provider offers interpretation of data & -.051 & .775 & .045 \\
\hline Environmental benefits & -.111 & .760 & .055 \\
\hline The source of the data & .032 & .757 & .065 \\
\hline Time saving & .214 & .644 & -.037 \\
\hline Technical support & .390 & .475 & .012 \\
\hline Quality data analysis & .383 & .438 & .117 \\
\hline Availability of data storage & -.119 & .137 &. .883 \\
\hline Availability of decision support tools & .168 & -.012 & .780 \\
\hline
\end{tabular}

\section{Results of Factor Analysis of Reasons for Using Technologies}

Table 21 shows the results of factor analysis of reasons why farmers choose to use technologies on their farms. The results show that, increased yield and time savings had the highest loadings thus were selected as independent variables for the binary logistic regression model. 
Table 21:

Results of Factor Analysis of Reasons for Using Technologies

\begin{tabular}{|l|c|c|}
\hline Reasons for using technologies & \multicolumn{2}{c|}{ Component } \\
\hline & $\mathbf{1}$ & $\mathbf{2}$ \\
\hline Increased yield & $\mathbf{. 8 4 2}$ & -.055 \\
\hline Increased farm profit & .790 & .032 \\
\hline Increased productivity & .773 & -.004 \\
\hline Reduced input & .712 & .055 \\
\hline Ease of recordkeeping & -.193 & $\mathbf{. 9 2 3}$ \\
\hline Ease of documentation & -.042 & .886 \\
\hline Time saving & .188 & .558 \\
\hline Allows me to be innovative & .194 & .482 \\
\hline
\end{tabular}

\section{Results of Factor Analysis of Reasons for Not Using Technologies}

Table 22 shows the results of factor analysis of reasons why farmers would not use technologies on their farms. The results show that, difficulty with understanding the data, size of operation (too small to justify) and, high cost of investment had the highest loadings thus were selected as independent variables for the binary logistic regression model.

Table 22:

Results of Factor Analysis of Reasons for not Using Technologies

\begin{tabular}{|l|c|c|c|}
\hline Reasons for not using technologies & \multicolumn{3}{|c|}{ Component } \\
\hline & $\mathbf{1}$ & $\mathbf{2}$ & $\mathbf{3}$ \\
\hline Difficulty with understanding the data & $\mathbf{. 9 1 1}$ & -.030 & .044 \\
\hline Difficulty with learning technology & .865 & -.001 & .069 \\
\hline Difficulty with using technology & .846 & -.019 & .127 \\
\hline Close to retirement or farm transition & .558 & .416 & -.216 \\
\hline Size of operation (too small to justify) & .021 & .857 & -.070 \\
\hline Uncertain return on investment (ROI) & -.059 & .783 & .121 \\
\hline Not worth my time & .107 & .530 & .304 \\
\hline High cost investment & -.182 & .142 & .716 \\
\hline Lack of technical & .269 & -.087 & .673 \\
\hline Don't trust source of data & .192 & .062 & .621 \\
\hline
\end{tabular}




\section{Poisson Regression Results}

Table 23 shows the results of the Poisson regression model. Though not statistically significant, farmer's age; had a negative parameter estimate. This result is consistent with the existing literature (Castle et al. 2016; Watcharaanantapong et al, 2014; Walton et al, 2010; Paxton et al, 2010; Larson et al, 2008; Daberkow \& McBride, 2003).

The results showed a positive and statistically significant with a small parameter estimate for acres farmed. Thus, for every 1,000 increase in the land of acres farmed by farmers, there is a 0.04 chance of an increase in the number of technologies used on the farm. This finding is also consistent with the literature (Castle et al. 2016; Lambert et al. 2015; Walton et al. 2010; Larson et al. 2008; Daberkow \& McBride, 2003).

Adoption group has a positive parameter estimate and a statistically significant relationship with the number of technologies adopted. This finding means that; farmers who are at the forefront and above average in the adoption of technologies are more likely to adopt a high number of technologies compared to farmers who are slowly catching up and have a long way to go with the adoption of new technologies. 
Table 23:

Poisson Regression Results

Variable

(Intercept)

\section{Poisson Model}

Parameter Estimate

Farmers' Age

Education

Acres Farmed

Adoption Group

Cybersecurity Threats

\section{Lack of Skilled Personnel for Data}

Interpretation

Storage Capacity

Who Uses my Farm Data

Significance at the 1 percent is indicated by triple asterisks respectively.
1.881

\begin{tabular}{|c|c|}
\hline $\begin{array}{c}\text { Standard } \\
\text { Error }\end{array}$ & p-value \\
\hline .2652 & $.000 * * *$ \\
\hline .0025 & .533 \\
\hline .0185 & .961 \\
\hline $9.5736 \mathrm{E}-006$ & $.000 * * *$ \\
\hline .0665 & $.000 * * *$ \\
\hline .0899 & .118 \\
\hline .0630 & .588 \\
\hline .0608 & .331 \\
\hline .1318 & .117 \\
\hline
\end{tabular}

\begin{tabular}{l|l|l}
-.002 & .0025 & .533
\end{tabular}

.00

$3.766 \mathrm{E}-005$

.428

$-.141$

.034

.059

$-.206$

.117

\section{Binary Logistic Regression Results}

In identifying the predictors of the adoption groups of farmers, the following variables were included in the binary logistic model as independent variables: farmer's age, education level, acres farmed, availability of data storage, ease of use of technology, the interpretation of data is provided to a farmer by service provider, increased yield, high cost of investment, size of operation too small as a reason for not using technology, number of technologies used by farmers, and difficulty understanding the data. Table 22 shows the results of the binary regression model. The model was statistically significant in identifying the factors that affect the dependent variable. The results show a Pseudo $\mathrm{R}^{2}$ of .535 which indicates that, 53.5 percent 
variance in the response variable was explained by the model. Using a .05 significance level, age, educational level of farmers, number of technologies used by farmers, difficulty understanding the data and increased yield were statistically significant. The odds ratio of age shows that, all things being constant, as the age of farmers increase by a year, the likelihood of farmers being early adopters reduces by $3 \%$. With educational level, since the odds ratio was more than one (1.5), a one unit increase in the level of education of farmers will increase the estimated odds of farmers being early adopters by $50 \%$.

The number of technologies used by the farmer was also statistically significant. This indicates that, a unit increase in the number of technologies used on the farm will increase the estimated odds of farmers being early adopters by $70 \%$. Increase in yield as a reason for using technology was statistically significant and had a negative parameter estimate. This means that, farmers who believe the use of technologies on their farm will increase their farm yield were $80 \%$ more likely to be late adopters. Difficulty with understanding the data as a reason for not using technology on the farm was statistically significant. This indicates that, farmers who would not use technologies on their farm because of difficulties with understanding the data were $186 \%$ more likely to be early adopters. 
Table 24:

Binary Logistic Regression Results

\begin{tabular}{|c|c|c|c|c|c|c|}
\hline \multirow{2}{*}{$\begin{array}{l}\text { Variable } \\
\text { Age }\end{array}$} & \multirow{2}{*}{$\begin{array}{c}\text { Coefficient } \\
-.036^{* *} \\
\end{array}$} & \multirow{2}{*}{$\begin{array}{c}\text { Std. Error } \\
.018 \\
\end{array}$} & \multirow{2}{*}{$\begin{array}{r}\mathbf{P}>\mathbf{z} \\
.049\end{array}$} & \multirow{2}{*}{$\begin{array}{c}\operatorname{Exp}(\mathbf{B}) \\
.965\end{array}$} & \multicolumn{2}{|c|}{$\begin{array}{c}\text { 95\% Conf. } \\
\text { Interval } \\
\end{array}$} \\
\hline & & & & & .931 & 1.000 \\
\hline Edu & $.401 * * *$ & .139 & .004 & 1.493 & 1.138 & 1.959 \\
\hline Acres & .000 & .000 & .781 & 1.000 & 1.000 & 1.000 \\
\hline Datasto & -.354 & .626 & .572 & .702 & .206 & 2.395 \\
\hline Etechuse & -2.961 & 1.695 & .081 & .002 & .002 & 1.435 \\
\hline Serprointer & .599 & .615 & .330 & 1.821 & .545 & 6.079 \\
\hline Yield & $-1.594 * *$ & .774 & .039 & .203 & .045 & .925 \\
\hline Reckeep & -.890 & .910 & .328 & .411 & .069 & 2.443 \\
\hline Highcost & .159 & .625 & .799 & 1.172 & .344 & 3.991 \\
\hline Sizeop & .803 & .441 & .069 & 2.231 & .939 & 5.300 \\
\hline Numbtech & $.524 * * *$ & .121 & .000 & 1.689 & 1.333 & 2.140 \\
\hline Diffunderstanding & $1.052 * *$ & .427 & .014 & 2.863 & 1.240 & 6.611 \\
\hline Constant & -1.610 & 2.418 & .505 & .200 & & \\
\hline \multicolumn{7}{|c|}{$\begin{array}{l}\text { Number of observations }=178 \\
\text { LR Chi }=91.015 \\
\text { Prob }>\text { Chi }=0.000 \\
\text { Pseudo } \mathrm{R}^{2}=0.535 \\
\text { Significance at the } 5 \text { percent and } 1 \text { percent are indicated by double and triple asterisks } \\
\text { respectively. }\end{array}$} \\
\hline
\end{tabular}




\section{CHAPTER V: CONCLUSIONS AND RECOMMENDATIONS}

\section{Conclusions}

The purpose of this study is to identify factors that influence U.S. agricultural producers' adoption of Big Data technologies focusing on the Midwestern region and some of the challenges these farmers encounter in the acquisition, use and control of the gathered data for production management and agricultural decision-making purposes. The current state of agriculture is experiencing an increase collection and use of data by both farmers and private firms. There are however concerns regarding ownership of farmers' data.

From this study, acres farmed, and adoption group were identified to influence the number of technologies adopted by farmers. Both acres farmed and adoption group were positively significant. The relationship between acres farmed, adoption group and number of technologies adopted should inform stakeholders the need to whether focus on small or large size farms and early or late adopters of technologies.

The results from the binary logistic showed, the age of farmers, increase in yield as a reason for using technology, difficulty with understanding the data as a reason for not using technology on the farm were statistically significant. This shows that, older farmers, and farmers who used technology for reason of increased yield were less likely to be early adopters. Farmers with high educational qualifications, farmers who used a higher number of technologies on their farms, and farmers who did not use technology by reason of difficulties with understanding data were more likely to be early adopters. 


\section{Recommendations}

Results from this study showed that, farmers who would not use technologies on their farm because of difficulties with understanding the data were more likely to be early adopters and farmers who believe the use of technologies on their farm will increase their farm yield were more likely to be late adopters. This result is unusual hence future research could further examine the reason for such findings as it would have been expected that, farmers who had difficulties with understanding data from their farms and as such would not use technologies and farmers who used technologies by reason of increased yield would be late adopters.

Farmers are increasingly becoming concerned about data ownership and access to their farm data. Majority are also skeptical about data companies' data storage practices. Precision agriculture technology manufacturers and relevant stakeholders should focus on developing a data exchange in which farm producers could be compensated for sharing their data. Again, further research must be conducted into how relevant stakeholders are protecting the farm data of farmers, what farmers are doing with the data they collect from their farms and the willingness of farmers to share their data with stakeholders given some level of incentive. This study focused on the technological (cost, veracity, benefits, time) and organizational (ownership, control, information systems competence) factors affecting the adoption of Big Data as categorized by Yadegaridehkordi et al. (2018). Further research should therefore focus on the environmental factors affecting the adoption of Big Data technologies. 


\section{REFERENCES}

Abdulai, S., Zakariah, A., \& Donkoh, S. A. (2018). Adoption of rice cultivation technologies and its effect on technical efficiency in Sagnarigu District of Ghana. Cogent Food \& Agriculture, 4(1). https://doi.org/10.1080/23311932.2018.1424296

Agrawal, K. P. (2015). Investigating the determinants of Big Data Analytics (BDA) adoption in asian emerging economies. 2015 Americas Conference on Information Systems, AMCIS 2015, 1-18. https://doi.org/10.5465/ambpp.2015.11290abstract

Almeida, J., Farias, J., \& Carvalho, H. (2017). Drivers of the Technology Adoption In Healthcare. Brazilian Business Review, 14(3), 336-351. https://doi.org/10.15728/bbr.2017.14.3.5

Anderson, E.; Darr, M.; Heckert, K.; Jones, B.; Lemke, D.; Miller, D.; (2014) “The Digital Transformation of Row Crop agriculture." A “Big Data” Project Report for the Iowa AgState Group, December 2014. Retrieved November 21, 2019 from https://www.iowafarmbureau.com/page/file?path=Files\%2Fwebsite\%2FNews\%2FPDFs \%2Fagesmed.pdf.

Banham, R. (2014). “Who Owns Farmers' Big Data?” Forbes. http://www.forbes.com/sites/emc/2014/07/08/who-owns-farmers-big-data/.

Basso B.; Dobrowolski J.; McKay C. (2017). From the Dust Bowl to Drones to Big Data: The Next Revolution in Agriculture, 18 Geo. J. Int'l Aff. 158 (2017). Provided by Milner Library, Illinois State University.

Boyer, A., Engleking, E., \& Gudas, S. (2015). Farmer perceptions of big data in agriculture. Journal of Purdue Undergraduate Research, 5, 82-83. http://dx.doi.org/10.5703/1288284315654 
Brase T., (2000). Online Companion for Precision Agriculture, DELMAR CENGAGE

LEARNING.http://www.delmarlearning.com/companions/content/140188105X/trends/ trends.asp

Bremser, C., Piller, G. and Rothlauf, F. (2017). "Strategies and Influencing Factors for Big Data Exploration.” In: Proceedings of the 23rd American Conference on Information Systems.

Britt, C. L., Rocque, M., \& Zimmerman, G. M. (2018). The Analysis of Bounded Count Data in Criminology. Journal of Quantitative Criminology, 34(2), 591-607. https://doi.org/10.1007/s10940-017-9346-9

Bronson, K., and Irena K. (2016). "Big Data in Food and Agriculture.” Big Data and Society 3 (1): 1-5. https://doi.org/10.1177/2053951716648174.

Burwood-Taylor, L.; Leclerc R.; \& Tilney M. (2015). “Agtech Investing Report 2015.” https://research.agfunder.com/2015/AgFunder-AgTech-Investing-Report-2015.pdf.

Carbonell, I. M. (2016). The ethics of big data in big agriculture. Internet Policy Review, 5(1). DOI: $10.14763 / 2016.1 .405$

Castle, Michael H.; Lubben, Bradley D.; and Luck, Joe D. (2016). "Factors Influencing Producer Propensity for Data Sharing \& Opinions Regarding Precision Agriculture and Big Farm Data" (2016). Presentations, Working Papers, and Gray Literature: Agricultural Economics.48. http://digitalcommons.unl.edu/ageconworkpap/48

Castle, Michael H.; Lubben, Bradley D.; and Luck, Joe D., (2015). "Precision Agriculture Usage and Big Agriculture Data” Cornhusker Economics (2015). Retrieved November 30, 2019 from https://agecon.unl.edu/documents/2369805/20977275/5-27-15.pdf/5-27-15.pdf 
Coble, K. H., Mishra, A. K., Ferrell, S., \& Griffin, T. (2018). Big data in agriculture: A challenge for the future. Applied Economic Perspectives and Policy, 40(1), 79-96. https://doi.org/10/1093/aepp/ppx056

Daberkow, S.G. \& McBride W. (2003). "Farm and Operator Characteristics Affecting the Awareness and Adoption of Precision Agriculture Technologies in the US.” Precision Agriculture 4 (2003): 163-177

Damanpour, F., and Schneider, M. (2006). "Phases of the Adoption of Innovation in Organizations: Effects of Environment, Organization and Top Managers," British Journal of Management (17:3), pp. 215-236

Daberkow, S.G. \& McBride W. (2003). "Farm and Operator Characteristics Affecting the Awareness and Adoption of Precision Agriculture Technologies in the US.” Precision Agriculture 4 (2003): 163-177.

Day, S. (2020). "Farm Tech Market Map: Why it's Time to Distinguish Farm Tech from the Messy Supply Chain" https://betterfoodventures.com/agtech-landscapes/farm-techlandscape- 2020

De Mauro, A.; Greco M.; Grimaldi, M.; (2016). “A Formal Definition of Big Data Based on its Essential Features. Libr. Rev. 65, 122-135

Dillman, D. A., L. M. Christian, and J. D. Smyth. (2014). Internet, Phone, Mail, and MixedModeSurveys: The Tailored Design Method. Hoboken, NJ: Wiley.

Elezaj, O., \& Tole, D. (2018). Big Data: Potential, Challenges, and Implications in Official Statistics. CBU International Conference Proceedings, 6, 95-99. https://doi.org/10.12955/cbup.v6.1139 
Erickson, B., Lowenberg-DeBoer, J., and Bradford, J. (2017). Precision agriculture dealership survey. Departments of Agricultural Economics and Agronomy, Purdue University, December. [Online]. Available from https://agribusiness.purdue.edu/wpcontent/uploads/2019/07/croplife-purdue-2017-precision-dealer-survey-report.pdf

Estes, V. (2016). "How Big Data is Disrupting Agriculture from Biological Discovery to Farming Practices." https://agfundernews.com/how-big-data-is-disrupting-agriculturefrom-biological-discovery-to-farming-practices5973.html

Food \& Agriculture Organization. (2016). Big Data: Unlocking the Future of Agriculture. http://aims.fao.org/activity/blog/big-data-unlocking-future-agriculture

Feder, G., Just, R. E., and Zilberman, D. (1985). “Adoption of Agricultural Innovations in Developing Countries: A Survey." Economic Development and Cultural Change, 33(2), 255-298.

Gedikoglu, H. “Adoption of Nutrient Management Practices" (2008). Theses and Dissertation. Griffin, T.W., Miller, N.J., Bergtold, J., Shanoyan, A., Sharda, A., and Ciampitti, I.A. (2017). Farm's sequence of adoption of information-intensive precision agricultural technology. Appl. Eng. Agric. 33(4): 521-527. doi:10.13031/aea.1222.

Gustafson, M. (2014). Big data and agriculture.

Haire, B., (2014). Ag Data: Its Value, Who Owns It and Where's It Going? Southeast Farm Press. http://southeastfarmpress.com/cotton/ag-data-its-value-who-owns-it-andwhere-s-itgoing

Hoselton, G. S. W. (2019). “Illinois Corn Farmers' Concerns About Nutrient Loss and The Adoption of Best Management Practices”. Theses and Dissertations. 1051. https://ir.library.illinoisstate.edu/etd/1051 
Johnson, S. A. (2019). "Impact of Selected Financial Measures on the Term Debt Repayment Ability of Illinois Grain Farms". Theses and Dissertations. 1109. https://ir.library.illinoisstate.edu/etd/1109

Kamilaris, A., Kartakoullis, A., \& Prenafeta-Boldú, F. X. (2017). A review on the practice of big data analysis in agriculture. Computers and Electronics in Agriculture, 143, 23-37. https://doi.org/10.1016/j.compag.2017.09.037

Kouzes, R. T., Anderson, G. A., Elbert, S. T., Gorton, I., \& Gracio, D. K. (2009). The changing paradigm of data-intensive computing. Compute, 1, pp. 26-34.

Labrinidis, A. \&., \& Jagadish, H. (2012). Challenges and opportunities with big data. Proceedings of the VLDB Endowmen, 5(12), pp. 2032-2033.

Lambert, D.M., K. P. Paudel, \& J. A. Larson. (2015). “Bundled Adoption of Precision Agriculture Technologies by Cotton Producers." Journal of Agricultural and Resource Economics 40(2) (2015): 325-345.

Larson, J.A., Roberts R.K., English B.C., Larkin S.L., Marra M.C., Martin S.W., Paxton K.W., \& Reeves J.M. (2007). "Factors Influencing Adoption of Remotely Sensed Imagery for Site Specific Management in Cotton Production." Precision Agriculture 9 (2008): 195-208.

Manyika, J., Chui M., Brown, B., Bughin, J., Dobbs, R., Roxburgh, C., \& Hung Byers, A. (2011). Big data: The next frontier for innovation, competition and productivity. McKinsey Global Institute, June, 156. https://bigdatawg.nist.gov/pdf/MGI_big_data_full_report.pdf

Mark, T. B., Griffin, T. W., \& Whitacre, B. E. (2016). The Role of Wireless Broadband Connectivity on 'Big Data' and the Agricultural Industry in the United States and Australia. The Role of Wireless Broadband Connectivity on 'Big Data' and the Agricultural Industry in the United States and Australia, 19, 43-56. 
National Research Council. (1997). Precision Agriculture in the 21st Century: Geospatial and Information Technologies in Crop Management, Committee on Assessing Crop Yield: SiteSpecific Farming, Information Systems, and Research Opportunities, Washington DC: National Academy Press. http://www.nap.edu/catalog/5491/precision-agriculture-in-the21st-century-geospatial-and-information-technologies.

Paxton, K., Mishra, A., Chintawar, S., Larson, J., Roberts, R., English, B., Lambert, D., Marra, M., Larkin, S., Reeves, J., \& Martin, S. (2010). Precision agriculture technology adoption for cotton production. Southern Agricultural Economics Association Annual Meeting, 21. Pham, X. \& Stack, M. (2018). “How Data Analytics Is Transforming Agriculture.” Business Horizons 61 (1): 125-33. https://doi.org/10.1016/j.bushor.2017.09.011.

Rains, G.C., and Thomas, D.L. (2009). Precision farming: An introduction. Bulletin 1186. Cooperative Extension Service, University of Georgia, Athens, GA. https://pdfs.semanticscholar.org/671d/74885acc484fcb4d9dcb04e95b8395e5131b.pdf

Richterich, A. (2018). Examining (Big) Data Practices and Ethics. The Big Data Agenda, 15-32. https://doi.org/10.2307/j.ctv5vddsw.4

Rogers, E. M. (1983). Diffusion of innovations. New York: The Free Press, 1983.

Schimmelpfennig, D. (2016). "Farm Profits and Adoption of Precision Agriculture." Economic Research Report, no. October 2016: 46. https://www.ers.usda.gov/webdocs/publications/80326/err217_summary.pdf?v=0.

Schimmelpfennig, D., and Ebel, R. (2016). Sequential adoption and cost savings from precision agriculture. J. Agric. Resource. Econ. 41(1): 97-115. https://ageconsearch.umn.edu/record/230776? $1 \mathrm{n}=\mathrm{en}$ 
Schimmelpfenning, D. and R. Ebel. (2011). On the Doorstep of the Information Age: Recent Adoption of Precision Agriculture. U.S. Department of Agriculture, Economic Research Service, Washington, D.C.

Shekhar, S., Schnable, P., Lebauer, D., Baylis, K., \& Vanderwaal, K. (2017). Agriculture big data (AgBD) challenges and opportunities From farm to table: A Midwest Big Data Hub community whitepaper. Machine Learning: Farm-to-Table, April 2017, 1-12. https://pdfs.semanticscholar.org/c815/75e059a826f39b47367fceaac67a8f55fb07.pdf Shickler, P. (2015). "Opinion: Keeping Farmers in the Driver's Sear with Their Farm Data." Agri-Pulse. http://www.agri-pulse.com/OpinionKeeping-farmers-in-the-drivers-seat-withtheir-farm-data-12292014.asp.

Singh, S. \& Jack, K. (2014). “Farmers Press Agribusiness Giants for Data Security.” Bloomberg Business. http://www.bloomberg.com/bw/articles/2014-01-23/farmers-press-agribusinessgiantsfor-data-security

Sonka, S. (2015). Big Data: from hype to agricultural tool. Policy Journal, 12, 1-9. https://doi.org/10.1145/2611040.2611042

Strobel, J. (2015). Reprinted And Distributed with Permission of the Drake Journal of Agricultural Law Agriculture Precision Farming: Who Owns The Property Of Information? Is it the Farmer, the Company Who Helps Consults the Farmer on How to Use the Information Best, or the Mechanical Company Who Built the Technology Itself? 239-256.

Stubbs, M. (2016). Big Data in U.S. Agriculture. Congressional Research Service, 1-14. https://www.fas.org/sgp/crs/misc/R44331.pdf 
Surbakti, F. P. S., Wang, W., Indulska, M., \& Sadiq, S. (2020). Factors influencing effective use of big data: A research framework. Information and Management, 57(1). https://doi.org/10.1016/j.im.2019.02.001

Sykuta, M. E. (2016). "Big Data in Agriculture: Property Rights, Privacy and Competition in Ag Data Services.” International Food and Agribusiness Management Review 19: 57-74

Taylor J. \& Whelan, B. (2005). A General Introduction to Precision Agriculture, Grain Research and Dev. Corp. 2 (Australian Center for Precision Agriculture), available at http://www.agriprecisione.it/wpcontent/uploads/2010/11/general_introduction_to_precision _agriculture.pdf

Tene, O. \& Polonetsky, J. (2013). Northwestern Journal of Technology and Intellectual Property Big Data for All: Privacy and User Control in the Age ofAnalytics (Vol. 11, Issue 5). http://scholarlycommons.1aw.northwestern.edu/njtip/voll

Turland, M.G. (2018). 'Farmers' Willingness to Participate in a Big Data Sharing Program: A Study of Saskatchewan Grain Farmers". Theses and dissertations https://harvest.usask.ca/bitstream/handle/10388/11053/TURLAND-THESIS2018.pdf? sequence $=1$ \&isAllowed $=y$

USDA ERS. (2020). Ag and Food Statistics: Charting the Essentials, October 2018. https://www.ers.usda.gov/webdocs/publications/90491/ap-080.pdf?v=502.2

USDA NASS. (2019). United States Summary and State Data. 2017 Census of Agriculture, 1 (April 2019).

Van Rijmenam, M. (2013). John Deere Is Revolutionizing Farming With Big Data. Datafloq,6-8. https://datafloq.com/read/john-deere-revolutionizing-farming-big-data/511 
Walton, J.C., Larson J.A., Roberts R.K., Lambert D.M., English B.C., Larkin S.L., Marra M.C., Martin S.W., Paxton K.W., Reeves J.M. (2010). "Factors Influencing Farmer Adoption of Portable Computers for Site-Specific Management: A Case Study for Cotton Production.” Journal of Agricultural and Applied Economics 42(2) (2010): 193-209.

Watcharaanantapong, P., Roberts R.K., Lambert D.M., Larson J.A., Velandia M., English B.C., Rejesus R.M., Wang C. (2014). “Timing of Precision Agriculture Technology Adoption in US Cotton Production.” Precision Agriculture 15 (2014): 427-446.

Whelan, B., \& Taylor, J. (2005). A General Introduction to Precision Agriculture. Australian Centre for Precision Agriculture, 29(1\&2), 79-94. https://doi.org/10.1111/14679973.00081

Wolfert, S., Ge, L., Verdouw, C., \& Bogaardt, M. J. (2017). Big Data in Smart Farming - A review. Agricultural Systems, 153, 69-80. https://doi.org/10.1016/j.agsy.2017.01.023

Yadegaridehkordi, E., Hourmand, M., Nilashi, M., Shuib, L., Ahani, A., \& Ibrahim, O. (2018). Influence of big data adoption on manufacturing companies' performance: An integrated DEMATEL-ANFIS approach. Technological Forecasting and Social Change, 137(July), 199-210. https://doi.org/10.1016/j.techfore.2018.07.043

Zarco-Tejada, P. J., Hubbard, N. \& Loudjani, P. (2014). Precision agriculture: an opportunity for EU farmers_-potential support with the CAP, 2014-2020, Joint Research Centre (JRC) of the European Commission; Monitoring Agriculture Resources (MARS) Unit H04 Available online at http://www.europarl.europa.eu/RegData/etudes/note/join/2014/ 529049/IPOL AGRI_NT\%282014\%29529049_EN.pdf Accessed 20 November 2019 Zmud, R. W., (1981). "Diffusion of Modern Software Practices: Influence of Organizational Process Variables" (1981). ICIS 1981 Proceedings. 22.https://aisel.aisnet.org/icis1981/22 


\section{APPENDIX A: SURVEY COVER LETTER AND CONSENT FORM}

Mail Version: Cover Letter / Informed Consent

You are being asked to participate in a research study conducted by Frederick Adomako a graduate student under the supervision of Dr. Aslihan Spaulding of the Agriculture Department at Illinois State University. The purpose of this study is to identify big data use on the farm and the challenges farmers encounter in their acquisition and control of big data on the farm. We want to examine big data tools farmers are using on the farm and how beneficial those tools are.

You are ineligible to participate if you are under the age of 18. Your participation in this study is voluntary. You will not be penalized if you choose to skip parts of the study, not participate, or withdraw from the study at any time.

If you choose to participate in this study, you will be asked to provide your opinion about various research questions. The first set of questions focus on demographic information. The second set of questions focus on technology use on the farm. The third set of questions focus on data sharing and ownership concerns. The final set of questions focus on challenges of data usage on the farm. In total, your involvement in this study will last approximately 20 minutes.

We do not anticipate any risks beyond those that would occur in everyday life. Your responses in the survey will be anonymous; nothing that will identify you will be linked to your responses. The findings from this study may be presented in conferences, meetings, and publications. When these findings are presented, your responses will be combined with the responses of other participants.

While you may not directly benefit from this study, your responses will help inform best research practices and develop guidelines for ethical research. Findings from this research will however be made available to you upon request.

If you have any questions concerning the research study, you can reach Frederick Adomako at (309) 826-7647, fadomak@,ilstu.edu. If you have any questions about your rights as a 
participant in this research, or if you feel you have been placed at risk, you can contact the Research Ethics \& Compliance Office at Illinois State University at (309) 438-5527 or irb@ilstu.edu.

Sincerely,

Frederick Adomako

Graduate Research Assistant

Department of Agriculture

Illinois State University

Check the box below if you are willing or ineligible to participate in this research.

$\square$ I am 18 or older and willing to participate in this study

$\square$ I am below 18 years and ineligible to participate in this study 


\section{Email Version: Cover Letter / Informed Consent}

You are being asked to participate in a research study conducted by Frederick Adomako a graduate student under the supervision of Dr. Aslihan Spaulding of the Agriculture Department at Illinois State University. The purpose of this study is to identify big data use on the farm and the challenges farmers encounter in their acquisition and control of big data on the farm. We want to examine big data tools farmers are using on the farm and how beneficial those tools are.

You are ineligible to participate if you are under the age of 18. Your participation in this study is voluntary. You will not be penalized if you choose to skip parts of the study, not participate, or withdraw from the study at any time.

If you choose to participate in this study, you will be asked to fill out the online survey. The first set of questions focus on demographic information. The second set of questions focus on technology use on the farm. The third set of questions focus on data sharing and ownership concerns. The final set of questions focus on challenges of data usage on the farm. In total, your involvement in this study will last less than fifteen minutes.

We do not anticipate any risks beyond those that would occur in everyday life and we will use all reasonable efforts to keep any provided personal information confidential. The data is saved in a password protected computer. After your data has been deidentified, your data may be used in other research projects. Information that may identify you or potentially lead to reidentification will not be released to individuals that are not on the research team. The findings from this study may be presented in conferences, meetings, and publications. When these findings are presented, your responses will be combined with the responses of other participants and aggregate data will be presented. However, when required by law or university policy, identifying information (including your signed consent form) may be seen or copied by authorized individuals.

While you may not directly benefit from this study, your responses will help inform farm technology use and benefits derived from them. Findings from this research will however be made available to you upon request. 
If you have any questions concerning the research study, you can reach Frederick Adomako at (309) 826-7647, fadomak@ilstu.edu. If you have any questions about your rights as a participant in this research, or if you feel you have been placed at risk, you can contact the Research Ethics \& Compliance Office at Illinois State University at (309) 438-5527 or irb@ilstu.edu.

Sincerely,

Frederick Adomako

Graduate Research Assistant

Department of Agriculture

Illinois State University
Dr. Aslihan D. Spaulding Professor of Agribusiness

Department of Agriculture

Illinois State University

Check the box below if you are willing to participate in this research.

You can print this form for your records.

I am 18 or older and willing to participate in this study.

I am not interested in participating in the study. 


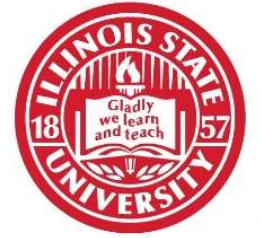

\section{DEPARTMENT OF AGRICULTURE \\ Illinois State University}

\section{BIG DATA TECHNOLOGY ON THE FARM SURVEY conducted by}

Frederick Adomako

Graduate Student

fadomak@ilstu.edu
Dr. Aslihan Spaulding

Professor of Agribusiness

Spaulding@IllinoisState.edu 
1. What is your gender? $\square$ Male - $1 \square$ Female- $2 \square$ Prefer not to answer -3

2. Which year were you born?

3. What is the highest level of education you have completed?

\begin{tabular}{|l|l|}
\hline$\square$ No formal education & $\square$ Some college \\
\hline$\square$ Some grade school & $\square$ Completed two-year college degree \\
\hline$\square$ Completed grade school & $\square$ Completed four-year college degree \\
\hline$\square$ Some high school & $\square$ Some graduate work \\
\hline$\square$ Completed high school & $\square$ Graduate degree (M.S., M.A, Ph.D., etc.) \\
\hline
\end{tabular}

4. How long have you been farming? years.

5. What is the zip code associated with your farm operation?

6. Please indicate how many acres you farmed in 2018. acres.

7. Which of the following crops do you raise?

\begin{tabular}{|l|c|c|}
\hline Crop & Yes & No \\
\hline Corn & $\square$ & $\square$ \\
\hline Soybean & $\square$ & $\square$ \\
\hline Wheat & $\square$ & $\square$ \\
\hline Other (please specify) & $\square$ & $\square$ \\
& & \\
\hline
\end{tabular}


8. Which of the following livestock do you raise for farm income?

\begin{tabular}{|l|c|c|c|}
\hline & $\begin{array}{c}\text { Yes, } \\
\text { We raise this } \\
\text { livestock }\end{array}$ & $\begin{array}{c}\text { If Yes, how many? } \\
\text { Number of } \\
\text { livestock }\end{array}$ & $\begin{array}{c}\text { No, - 2 } \\
\text { We do not raise } \\
\text { this livestock }\end{array}$ \\
\hline Beef cattle & $\square$ & & $\square$ \\
\hline Dairy cattle & $\square$ & & $\square$ \\
\hline Hogs & $\square$ & & $\square$ \\
\hline Sheep & $\square$ & & $\square$ \\
\hline Goats & $\square$ & & $\square$ \\
\hline Poultry & $\square$ & & $\square$ \\
\hline \begin{tabular}{l} 
Equine \\
\hline $\begin{array}{c}\text { Other (please } \\
\text { specify) }\end{array}$
\end{tabular} & $\square$ & & $\square$ \\
\end{tabular}

9. Please indicate the level of Gross Cash Farm Income (including crop and livestock sales, government payments and other farm-related income such as receipts from custom work, machine hire, livestock grazing fees, timber sales, outdoor recreation, production contract fees etc. generated by your farm operation in the fiscal year 2018?

\begin{tabular}{|l|}
\hline$\square$ Less than $\$ 150,000$ \\
\hline$\square \$ 150,000-\$ 349,999$ \\
\hline$\square \$ 350,000-\$ 999,999$ \\
\hline$\square \$ 1,000,000-\$ 4,999,999$ \\
\hline$\square \$ 5,000,000$ or more \\
\hline
\end{tabular}

10. Where do you see yourself in the technology adoption groups?

\begin{tabular}{|l|}
\hline$\square$ I am on the forefront of new technology \\
\hline$\square$ I am above average when it comes to adopting new technology \\
\hline$\square$ I am slowly catching up with new technology \\
\hline$\square$ I have a long way to go with new technology \\
\hline
\end{tabular}


11. Do you use any of the following technologies on your farm operations?

\begin{tabular}{|c|c|c|}
\hline Technology & Yes & No \\
\hline Field mapping & $\square$ & $\square$ \\
\hline Global Position System (GPS) guidance & $\square$ & $\square$ \\
\hline Grain Bin Controls & $\square$ & $\square$ \\
\hline Grain Bin Monitors & $\square$ & $\square$ \\
\hline Moisture sensors & $\square$ & $\square$ \\
\hline Planter sensors & $\square$ & $\square$ \\
\hline Soil sampling on a grid & $\square$ & $\square$ \\
\hline $\begin{array}{l}\text { Unmanned Aerial Vehicles (UAVs) - } \\
\text { Drones }\end{array}$ & $\square$ & $\square$ \\
\hline Variable Rate Fertilizer Technology & $\square$ & $\square$ \\
\hline Variable Rate Planting Technology & $\square$ & $\square$ \\
\hline Yield monitor & $\square$ & $\square$ \\
\hline Zone sampling & $\square$ & $\square$ \\
\hline Other (please specify) & $\square$ & $\square$ \\
\hline
\end{tabular}

12. Do you collect data from the technology used on the farm?

$\square$ Yes (if checked go to question 13) $\square$ No (if checked go to question 14)

13. How do you store the data collected from your farm operations?

\begin{tabular}{|l|l|l|}
\hline$\square$ I do not know & $\square$ Business Computer & $\square$ Server \\
\hline$\square$ Cloud & $\square$ Government agency & $\square$ Other (please specify) \\
\hline
\end{tabular}


14. How important are the following in choosing which big data technology to use?

\begin{tabular}{|l|c|c|c|}
\hline & $\begin{array}{c}\text { Extremely } \\
\text { important - } \\
\mathbf{1}\end{array}$ & $\begin{array}{c}\text { Moderately } \\
\text { important - } \\
\mathbf{2}\end{array}$ & $\begin{array}{c}\text { Not at all } \\
\text { important - } \\
\mathbf{3}\end{array}$ \\
\hline Availability of data storage & $\square$ & $\square$ & $\square$ \\
\hline Availability of decision support tools & $\square$ & $\square$ & $\square$ \\
\hline Cost of the service & $\square$ & $\square$ & $\square$ \\
\hline Ease of interpretation of data & $\square$ & $\square$ & $\square$ \\
\hline Ease of use of the data & $\square$ & $\square$ & $\square$ \\
\hline $\begin{array}{l}\text { Ease of use of technology } \\
\text { Economic benefits from using the } \\
\text { technology }\end{array}$ & $\square$ & $\square$ & $\square$ \\
\hline $\begin{array}{l}\text { Environmental benefits } \\
\text { Quality of data analysis }\end{array}$ & $\square$ & $\square$ & $\square$ \\
\hline $\begin{array}{l}\text { Service provider offers interpretation of } \\
\text { data }\end{array}$ & $\square$ & $\square$ & $\square$ \\
\hline Time saving & $\square$ & $\square$ & $\square$ \\
\hline Source of the data & $\square$ & $\square$ & $\square$ \\
\hline Technical support & $\square$ & $\square$ & $\square$ \\
\hline User friendly & $\square$ & $\square$ \\
\hline
\end{tabular}


15. Do you agree with the following statements?

\begin{tabular}{|l|c|c|}
\hline & Yes & No \\
\hline I am able to store data generated on my farm. & $\square$ & $\square$ \\
\hline I know how to use data generated on my farm. & $\square$ & $\square$ \\
\hline $\begin{array}{l}\text { I know how to interpret data generated on my farm for decision } \\
\text { making. }\end{array}$ & $\square$ & $\square$ \\
\hline I know who has access to my farm data. & $\square$ & $\square$ \\
\hline \begin{tabular}{l} 
I know how to protect my farm data. \\
\hline $\begin{array}{l}\text { I acquire data from other sources for decision making purposes on } \\
\text { my farm. }\end{array}$
\end{tabular} & $\square$ & $\square$ \\
\hline $\begin{array}{c}\text { Big data will transform how we do things on the farm in the next 20 } \\
\text { years. }\end{array}$ & $\square$ & $\square$ \\
\hline
\end{tabular}

16. How would you prefer to access the services from technology providers? (Please select all that apply)

\begin{tabular}{|l|l|}
\hline$\square$ Text Message & $\square$ Website \\
\hline $\begin{array}{l}\square \text { One-on-one } \\
\text { meeting }\end{array}$ & $\square$ Email \\
\hline$\square$ Mobile app & $\square$ Other (please specify) \\
\hline
\end{tabular}

\section{To whom do you think farm data belongs to? (Select all that apply)}

\begin{tabular}{|l|l|}
\hline$\square$ The farmer & $\begin{array}{l}\square \text { The company that manufactured the } \\
\text { equipment }\end{array}$ \\
\hline$\square$ The equipment dealer & $\square$ Other (please specify) \\
\hline$\square$ The input provider & \\
\hline
\end{tabular}


18. Are you comfortable with sharing your farm data with the following?

\begin{tabular}{|l|c|c|}
\hline & $\begin{array}{r}\text { Yes - } \\
\mathbf{1}\end{array}$ & No - 2 \\
\hline Crop insurance provider & $\square$ & $\square$ \\
\hline $\begin{array}{l}\text { Equipment } \\
\text { Manufacturers }\end{array}$ & $\square$ & $\square$ \\
\hline Financial Institutions & $\square$ & $\square$ \\
\hline Grower Associations & $\square$ & $\square$ \\
\hline Input Suppliers & $\square$ & $\square$ \\
\hline Salespeople & $\square$ & $\square$ \\
\hline State agency & $\square$ & $\square$ \\
\hline University Researchers & $\square$ & $\square$ \\
\hline USDA & $\square$ & $\square$ \\
\hline Other federal agency & $\square$ & $\square$ \\
\hline None of the above & $\square$ & $\square$ \\
\hline Other (please specify) & $\square$ & $\square$ \\
& & \\
& & \\
\hline
\end{tabular}


19. Which of the following do you consider as concern in regard to farm data?

\begin{tabular}{|c|c|c|}
\hline $\begin{array}{l}\text { I am concerned } \\
\quad \text { about } \ldots \ldots \ldots \ldots \ldots \ldots \ldots \ldots \ldots\end{array}$ & Yes & No \\
\hline Access to data from other sources & $\square$ & $\square$ \\
\hline Availability of decision support tools & $\square$ & $\square$ \\
\hline Cyber security threats & $\square$ & $\square$ \\
\hline How my data is protected & $\square$ & $\square$ \\
\hline How my farm data is shared & $\square$ & $\square$ \\
\hline Lack of skilled personnel for data analysis & $\square$ & $\square$ \\
\hline $\begin{array}{l}\text { Lack of skilled personnel for data } \\
\text { interpretation }\end{array}$ & $\square$ & $\square$ \\
\hline Quality of the data from other sources & $\square$ & $\square$ \\
\hline Storage cost & $\square$ & $\square$ \\
\hline Storage capacity & $\square$ & $\square$ \\
\hline Who has access to my farm data & $\square$ & $\square$ \\
\hline Who owns my data & $\square$ & $\square$ \\
\hline Who uses my farm data & $\square$ & $\square$ \\
\hline
\end{tabular}

20. Which of the following would you consider as a reason for using data technologies on your farm? (Please select all that apply).

\begin{tabular}{|l|c|c|}
\hline Reason for using & Yes & No \\
\hline $\begin{array}{l}\text { Allows me to be } \\
\text { innovative }\end{array}$ & $\square$ & $\square$ \\
\hline Ease of documentation & $\square$ & $\square$ \\
\hline Ease of recordkeeping & $\square$ & $\square$ \\
\hline Increased farm profit & $\square$ & $\square$ \\
\hline Increased productivity & $\square$ & $\square$ \\
\hline Increased yield & $\square$ & $\square$ \\
\hline Reduced input costs & $\square$ & $\square$ \\
\hline Time saving & $\square$ & $\square$ \\
\hline
\end{tabular}


21. Which of the following would you consider as a reason for NOT using data technologies on your farm? (Please select all that apply).

\begin{tabular}{|l|c|c|}
\hline Reason for NOT using & Yes & No \\
\hline Close to retirement or farm transition & $\square$ & $\square$ \\
\hline Difficulty with learning technology & $\square$ & $\square$ \\
\hline Difficulty with understanding the data & $\square$ & $\square$ \\
\hline Difficulty with using technology & $\square$ & $\square$ \\
\hline Do not trust source of data & $\square$ & $\square$ \\
\hline High cost of investment & $\square$ & $\square$ \\
\hline Lack of technical support & $\square$ & $\square$ \\
\hline Not worth my time & $\square$ & $\square$ \\
\hline Size of operation (too small to justify) & $\square$ & $\square$ \\
\hline Uncertain return on investment (ROI) & $\square$ & $\square$ \\
\hline Other (please specify) & $\square$ & $\square$ \\
\hline
\end{tabular}


22. Do you have a contract with any of the following companies? If you do, please indicate the services you receive from them.

\begin{tabular}{|c|c|c|c|c|c|c|c|c|}
\hline \multirow[b]{2}{*}{$\begin{array}{l}\text { Name of } \\
\text { Company }\end{array}$} & \multicolumn{2}{|c|}{$\begin{array}{l}\text { Have a } \\
\text { contract }\end{array}$} & \multicolumn{6}{|c|}{ Services you are receiving from the company } \\
\hline & Yes & No & $\begin{array}{c}\text { Data } \\
\text { Collection }\end{array}$ & $\begin{array}{c}\text { Data } \\
\text { Analysis }\end{array}$ & $\begin{array}{c}\text { Data } \\
\text { Interpretation }\end{array}$ & $\begin{array}{l}\text { Data } \\
\text { Storage }\end{array}$ & $\begin{array}{c}\text { Advisory } \\
\text { Services }\end{array}$ & $\begin{array}{c}\text { Other } \\
\text { (please } \\
\text { specify) }\end{array}$ \\
\hline $\begin{array}{l}\text { Agricultural } \\
\text { Data Coalition }\end{array}$ & $\square$ & $\square$ & $\square$ & $\square$ & $\square$ & $\square$ & $\square$ & $\square$ \\
\hline $\begin{array}{l}\text { Granular and } \\
\text { Encirca }\end{array}$ & $\square$ & 口 & $\square$ & $\square$ & $\square$ & $\square$ & $\square$ & $\square$ \\
\hline Conservis & $\square$ & $\square$ & $\square$ & $\square$ & $\square$ & $\square$ & $\square$ & $\square$ \\
\hline $\begin{array}{l}\text { Grower } \\
\text { Information } \\
\text { Services } \\
\text { Cooperative } \\
\text { (GiSC's) }\end{array}$ & $\square$ & $\square$ & 口 & $\square$ & $\square$ & $\square$ & $\square$ & $\square$ \\
\hline $\begin{array}{l}\text { Climate } \\
\text { Fieldview }\end{array}$ & $\square$ & $\square$ & $\square$ & $\square$ & $\square$ & $\square$ & $\square$ & $\square$ \\
\hline $\begin{array}{l}\text { Farmers } \\
\text { Business } \\
\text { Network (FBN) }\end{array}$ & $\square$ & $\square$ & 口 & $\square$ & $\square$ & $\square$ & $\square$ & $\square$ \\
\hline FarmLogs & $\square$ & $\square$ & $\square$ & $\square$ & $\square$ & 口 & $\square$ & $\square$ \\
\hline Farmers Edge & $\square$ & $\square$ & $\square$ & $\square$ & $\square$ & $\square$ & $\square$ & $\square$ \\
\hline Farm Mobile & $\square$ & $\square$ & $\square$ & $\square$ & $\square$ & $\square$ & $\square$ & $\square$ \\
\hline Graincoat & $\square$ & $\square$ & 口 & $\square$ & 口 & 口 & 口 & $\square$ \\
\hline $\begin{array}{l}\text { Blue River } \\
\text { Tech / John } \\
\text { Deere }\end{array}$ & $\square$ & 口 & 口 & $\square$ & $\square$ & 口 & 口 & $\square$ \\
\hline Mavrx & $\square$ & 口 & $\square$ & $\square$ & 口 & 口 & 口 & $\square$ \\
\hline Propera & 口 & $\square$ & $\square$ & $\square$ & $\square$ & $\square$ & 口 & $\square$ \\
\hline
\end{tabular}




\begin{tabular}{|l|c|c|c|c|c|c|c|c|}
\hline Terravion & $\square$ & $\square$ & $\square$ & $\square$ & $\square$ & $\square$ & $\square$ & $\square$ \\
\hline $\begin{array}{l}\text { Other (please } \\
\text { specify) }\end{array}$ & $\square$ & $\square$ & $\square$ & $\square$ & $\square$ & $\square$ & $\square$ & $\square$ \\
\hline
\end{tabular}

23. How did you hear about this project?

\begin{tabular}{|l|}
\hline$\square$ Illinois State University Social Media \\
Announcements \\
\hline$\square$ Email from Farm Progress Companies \\
\hline$\square$ Other (please specify \\
\hline
\end{tabular}

24. Please feel free to use the space below for any comment you have about the questionnaire or "Big Data" technologies. Thank you! 


\section{APPENDIX C: MAIL SURVEY: FOLLOW UP LETTER}

We hope you had a successful harvest and holiday season. At the beginning of November, we wrote to you seeking information on your use of data technologies on the farm. As of today, we have not yet received your completed survey. In the event that, your survey has been misplaced, a replacement is enclosed.

The purpose of this study is to identify data technology use on the farm and the challenges farmers encounter in their acquisition and control of data on the farm. We want to examine data tools farmers are using on the farm and how beneficial those tools are.

You are ineligible to participate if you are under the age of 18. Your participation in this study is voluntary. You will not be penalized if you choose to skip parts of the study, not participate, or withdraw from the study at any time.

If you choose to participate in this study, please fill out the survey and send it back to us along with this letter in the attached envelope. The first set of questions focus on demographic information. The second set of questions focus on technology use on the farm. The third set of questions focus on data sharing and ownership concerns. The final set of questions focus on challenges of data usage on the farm. In total, your involvement in this study will last less than fifteen minutes.

We do not anticipate any risks beyond those that would occur in everyday life and we will use all reasonable efforts to keep any provided personal information confidential. The data is saved in a password protected computer. After your data has been deidentified, your data may be used in other research projects. Information that may identify you or potentially lead to reidentification will not be released to individuals that are not on the research team. The findings from this study may be presented in conferences, meetings, and publications. When these findings are presented, your responses will be combined with the responses of other participants and aggregate data will be presented. However, when required by law or university policy, identifying information (including your signed consent form) may be seen or copied by authorized individuals. 
While you may not directly benefit from this study, your responses will help inform farm technology use and benefits derived from them. Findings from this research will however be made available to you upon request. An identification number has been assigned to each survey solely for the purpose of avoiding duplicate mailings and follow-ups with respondents.

If you have any questions concerning the research study, you can reach Frederick Adomako at (309) 826-7647, fadomak@ilstu.edu. If you have any questions about your rights as a participant in this research, or if you feel you have been placed at risk, you can contact the Research Ethics \& Compliance Office at Illinois State University at (309) 438-5527 or irb@ilstu.edu.

Frederick

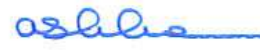

Frederick Adomako

Dr. Aslihan D. Spaulding

Graduate Research Assistant Professor of Agribusiness

Department of Agriculture Department of Agriculture

Illinois State University Illinois State University

$\square$ I am 18 or older and willing to participate in this study $\square$ I am not interested in participating in this study 